\title{
Alan Turing-ek morfogenesiaren inguruan egindako ikerketaren analisi matematikoa
}

\author{
(The Mathematical Analysis of Alan Turing's Research \\ on Morphogenesis)
}

\author{
Jone Apraiz Iza*, Idoia Marauri Bernedo
}

Matematika Saila, Zientzia eta Teknologia Fakultatea (UPV/EHU)

LABURPENA: Artikulu honetan, Alan Turing matematikariak 1952an morfogenesiaren inguruan aurkeztu zuen The Chemical Basis of Morphogenesis, [19], lanaren zati bat aurkeztu eta matematikoki garatuko dugu. Horretarako, beharrezkoak diren matematikako kontzeptuak eta baliabideak azalduko ditugu. Konkretuki, Alan Turingek [19] artikuluko «Reactions and Diffusion in a Ring of Cells» (eraztun diskretuko eremua) eta «Continuous Ring of Tissue» (eraztun jarraituko eremua) ataletan gehiegi sakondu edo zehaztu gabe erabili zituen ekuazio diferentzialak, erreakzio-difusio ekuazioak, Fourier-en serieak eta funtzioen linealizazioa azalduko ditugu, eta bi eremu horietan planteatutako ekuazio-sistemen soluzioak bilatzeko erabiliko ditugu. Artikulu hau UPV/EHUko Idoia Marauri ikasle ohiaren Gradu Amaierako Lanean oinarrituta dago.

HITZ GAKOAK: biologia matematikoa, morfogenesia, erreakzio-difusio ekuazioak, Fourierren serieak.

ABSTRACT: In this article, we show and mathematically develop a part of the work that the mathematician Alan Turing did on Morphogenesis which he published in 1952 in his article The Chemical Basis of Morphogenesis, [19]. We will explain the mathematical concepts and resources needed to do so: differential equations, reaction-diffusion equations, Fourier series and function linearization. Specifically, we will show and explain all these mathematical tools that Alan Turing used but did not develop nor delve into a lot in his [19] article's two sections: "Reactions and Diffusion in a Ring of Cells» (for the discrete ring region) and «Continuous Ring of Tissue» (for the continuous ring region). This article is based on the UPV/EHU former student Idoia Marauri's Final Degree Project.

KEYWORDS: mathematical biology, morphogenesis, reaction-diffusion equations, Fourier series.

\footnotetext{
* Harremanetan jartzeko / Corresponding author: Jone Apraiz lza. Matematika Saila, Zientzia eta Teknologia Fakultatea, Euskal Herriko Unibertsitatea (UPV/EHU), Sarriena auzoa, z/g (48940 Leioa). - jone.apraiz@ehu.eus - https://orcid.org/00000001-7866-8412

Nola aipatu / How to cite: Apraiz Iza, Jone; Marauri Bernedo, Idoia (2021). «Alan Turing-ek morfogenesiaren inguruan egindako ikerketaren analisi matematikoa». Ekaia, 41, 2021, 275-310. (https://doi.org/10.1387/ekaia.22214).

Jasotze-data: 2020, azaroak 5; Onartze-data: 2021, martxoak 30.

ISSN 0214-9753 - elSSN 2444-3581 / (c) 2021 UPV/EHU
}

cc)(i) $\Theta$ Lan hau Creative Commons Aitortu-EzKomertziala-LanEratorririkGabe 4.0 Nazioartekoa lizentzia baten mende dago 


\section{SARRERA}

Alan Mathison Turing 1912ko ekainaren 23an jaio zen, Warrington Lodge-n, Londresen. Turingek txikitatik izan zuen zientziarekiko miresmena, eta, 12 urte zituelarik, biologia, kimika eta fisikarekin erlazionatutako esperimentuak egiten hasi zen, liburuak irakurtzeaz gain, [20] liburuan argitaratutakoaren arabera. 1934an, Matematika ikasketak burutu zituen Cambridge Unibertsitateko King's College-en. Horren ostean, haren ikerketa-ildoak zein lan-ekoizpenak ugariak izan ziren. Besteak beste, honako zientzia-arlo hauek jorratu zituen: logika abstraktua, kriptanalisia, adimen artifiziala eta bizitza artifiziala.

Artikulu honetan, Turingek 1952an aurkeztu zuen morfogenesiari buruzko ikerketa-lanaren inguruan jardungo dugu, The Chemical Basis of Morphogenesis, [19]. Zehatzago, artikulu horretako seigarren eta zazpigarren ataletan, «Reactions and Diffusion in a Ring of Cells» (eraztun diskretuaren eremua) eta «Continuous Ring of Tissue» (eraztun jarraituaren eremua), agertzen diren matematikako kontzeptuak aurkeztu, azaldu eta garatuko ditugu. Horretarako, sarrera honetan, morfogenesia zer den aipatuko dugu, eta Turingek [19] artikuluan azaldutako ikerketaren helburua eta garrantzia aurkeztuko ditugu.

Morfogenesia enbriologiaren ${ }^{1}$ arlotzat har daiteke. Morfogenesi hitzak grekoan du jatorria: morphe eta genesis osagaiekin sortuta dago. Lehenengo osagaiak «forma» esan nahi du, eta bigarrenak «sorrera, hasiera edo jatorria». Beraz, morfogenesi hitzaren itzulpen literala «formaren jatorria» da. Morfogenesi terminoak, hortaz, barnean biltzen ditu organismo batek etorkizunean izango duen formaren sorrera-prozesua, zeina enbrioian gertatzen baita, eta garapen-prozesua.

Biologia matematikoaren sorreraren ${ }^{2}$ jatorrian ikertuz, $[6,49$. or.] eta $[1,2$. or.], D'Arcy Wentworth Thompson biologo eta matematikari eskoziarrarekin topo egiten dugu, bere On Growth and Form, [18], liburuaren argitalpenarekin ezagun egin zenarekin. Liburu horretan, oro har, fenomeno biologikoak matematikaren bidez adierazteko eta azaltzeko ahalegina egin zuen. Zehatzagoak izateko, eredu matematikoak aplikatu zituen patroi biologikoen eraketaren dinamikak azaltzeko. Gainera, erakutsi zuen matematikak, forma estatikoa deskribatzeaz gain, formen aldaketa ere deskriba dezakeela. Horrela, morfogenesiaren azalpen zientifikorako bidea hasi zuen, $[6,7$. or.]. Aipatu beharra dago Thompsonen lanek zein ideiek eragin handia izan zutela Turingengan, [1,2.2. atala].

\footnotetext{
${ }^{1}$ Ernalkuntzatik jaio arte enbrioiaren eraketa zein garapena aztertzen dituen biologiaren adarra da.

${ }^{2}$ Biologia matematikoaren historia [10] liburuan aurki daiteke, laburki.
} 
Thompsonez gain, badira biologiako sistema dinamiko konplexuak deskribatzen eta aztertzen jardun zuten beste ikertzaile batzuk ere. Esaterako, 1926an, V. Volterra italiar matematikari eta fisikariak eredu bat aurkeztu zuen, harrapari eta harrapakin diren bi espezieren arteko interakzioa deskribatzen duena. Horren ostean, 1935ean, N. Rashevsky ukraniar biologo, fisikari eta matematikariak, zelulen egituraren ikuspuntu matematikoa lantzeaz gain, nerbio-funtzioen teoria matematikoa txertatu zuen [15] artikuluan. Gainera, aipatzekoa da azken horrek lehenengo neurona-eredua aurkeztu eta neurona-sare artifizialaren ideia sortu zuela.

Turing biologia matematikoaren arloan ikertzen lehenengoa izan ez arren, esan daiteke 1952ko artikuluak eragin handia izan duela biologiaren eta enbriologiaren garapenean. Ikertzaile askok interesgarri eta iraultzaile iritzi zioten Turingen ereduari (eta gaur egun ere baderitzote), ideia sinpleen bidez emaitza esperimentalak azaltzea lortu zuelako. XX. eta XXI. mendeetan bizitza artifizialaren inguruan egin diren ikerketa askoren oinarria izan da Turingen ikerketa, biologiaren aldetik adibide gutxi aurkeztu bazituen ere. Adibide biologikoen kopurua zela-eta, Turingek berak adierazi zuen urritasunaren arrazoietako bat biologia-arloko fenomenoen konplexutasuna izan zitekeela.

Halaber, [19] artikulua aitzindarietako bat da animalien ilajeetako formen eraketa ikertzen duten lanetan ere. Lan hori oinarri hartuta, biologia matematikoaren arloan ikertzen jardun duten egileetako bat J.D. Murray matematikari ingelesa dugu. Murrayk animalien azaleko formen eraketamekanismoa geometriaren ikuspegitik aztertu zuen, kurbadura eta bestelako ezaugarri geometriko batzuk erabiliz. Gaur egun, Murrayk idatzitako Mathematical Biology: I. An Introduction liburua, [11], oso ezaguna da biologia matematikoaren esparruan.

1954ko azaroan argitaratu zen Cambridgeko King's College-eko urteko txostenean adierazten zen Turingek morfogenesiaren inguruan egindako ikerketaren xedea zela, modu idealizatuan eta sinplifikatuan bazen ere, frogatzea hasiera batean simetria esferikoa zuen zelula multzo bat simetria esferikorik ez zuen zerbait bihurtzen zela, [20, 196. or.].

[19] artikuluaren jatorria Turingek psikologiaz eta fisiologiaz zuen jakingura izan daiteke. Hain zuzen ere, arlo horietako prozesuak matematikaren bidez azaltzeko zuen gogoa. Ideia horiek garatzeko, Turingek konputazio-arloan egindako ibilbidea ezagututa, nabaria da bere ikerketa-ibilbidean zehar aztergai izan zituen automatak ${ }^{3}$ presente izan zituela (2.1.2. atalean jardungo dugu horretaz).

\footnotetext{
3 Automata zelular bat lauki-sare batean era bereizgarrian kokatutako koloredun gelaxka multzo bat da, denbora pauso diskretuetan zehar eta inguruko gelaxken egoeretan oinarritutako arauen bidez, modu iteratiboan (nahi bezain beste) eboluzionatzen duena.
} 
Morfogenesiaren inguruko artikuluan, animalien ilaje-patroiak sortzeko mekanismo kimikoak postulatu zituen, eta honako hau iradoki zuen: forma biologikoak substantzia kimikoen ${ }^{4}$ kontzentrazioetako aurrereduei jarraiki sortzen zirela, substantzia kimiko horiek elkarren artean erreakziona zezaketela eta ehunetan zehar heda zitezkeela. Dena den, Turingen helburua ez zen izan morfogene zehatzak deskribatzea edo morfogeneen sailkapena ematea. Aitzitik, modu abstraktuan, espezifikatu gabeko morfogeneen inguruko suposizio batzuk eginda, erreakzio-difusio ereduek forma bat baino gehiago sortuko zituztela frogatzea zuen helburu.

Horren harira, Alan Turingek proposatu zuen morfogeneak era «egokian» erreakzionatuz eta hedatuz gero, morfogeneen kontzentrazioetan espazio-patroiak era zitezkeela baldin eta hasierako zelulen bilduraren banaketa uniformea bazen. Hau da, hasierako substantzia kimikoen sistema «nahiko» homogeneoa izango balitz, denbora pasatu ahala, ausazko desorekek oreka-puntu ${ }^{5}$ homogeneoetan eragiten zituzten ezegonkortasunengatik $^{6}$, patroi bat baino gehiago garatuko liratekeela, Turingen patroi deritzenak (2.3. atalean azalduko dugu gehiago ideia iraultzaile horri buruz). Egoera horiek deskribatzeko, erreakzio-difusio ekuazioak erabili zituen tresnatzat, eta artikulu honetako 2.1. atalean azalduko ditugu.

Alan Turingek morfogenesiaz egindako ikerketari buruzko sarrera osatze aldera, bi zientzialari aipatuko ditugu. Bata, Rashevsky, hark idatzitako [15] artikuluan planteatu zuen galderak zerikusi zuzena duelako lan honen ardatz den artikuluarekin: «Zergatik daukagu daukagun itxura?». Bestea, J.W.S. Pringle zoologoa, [19] lanaz adierazi zuelako Turingek frogatu zuela, prozedura matematikoen bidez, hasiera batean homogeneoak diren zenbait sistema dinamikok heterogeneotasun-itxura lortu arte aldaketa mailakatuak jasaten dituztela, [20, 240. or.].

Artikulu honen bidez, irakurlea Alan Turingen morfogenesiaren inguruko ikerketan murgildu nahi dugu, haren lanaren eragina eta berezitasuna erakusteko. Era berean, biologiako eta kimikako hainbat prozesutan azterketak egiteko orduan edota ondorioak ateratzeko orduan matematikak duen garrantzia erakutsi nahi dugu.

Azkenik, sarrerarekin bukatzeko, artikulu honen egitura eta banaketa azalduko ditugu. 2. atalean, Alan Turingek [19] artikuluan erabili zituen matematikako tresnak eta kontzeptuak aurkeztu eta azalduko ditugu:

\footnotetext{
${ }^{4}$ Alan Turingek morfogene deitu zituen substantzia kimiko berezi batzuen existentzia onartu zuen, eta horiekin lanean jardun zuen, substantzia horiek zein ziren alde batera utzita.

${ }^{5}$ Ikus 2.3. atalean dagoen 1. definizioa, oreka-puntuaren definizioa ezagutzeko.

${ }^{6}$ Ikus 2.3. atalean dagoen 7. oharra, oreka-puntu egonkor eta ezegonkorrei buruz jakiteko.
} 
erreakzio-difusio ekuazioak, Fourierren serieak eta funtzioen linealizazioa. Ondoren, 3. atalean, [19] artikuluan morfogeneen portaera aztertu zen lehenengo eredua garatuko dugu, eraztun diskretua. Artikulu horretan, Turingek substantzia kimikoen portaera aztertzeko erabili zuen hurrengo eremua eraztun jarraituarena izan zen, eta guk artikulu honetako 4. atalean azalduko dugu. Azkenik, 5. atalean, Turingek [19] artikuluan txertatu zituen beste eremu eta atal batzuk aipatzeaz gain, emaitza matematiko teorikoetatik ondorio edo aplikazio biologikoak ateratzera nola hel gaitezkeen azalduko dugu.

\section{BALIABIDE MATEMATIKOAK}

Atal honetan, Alan Turingek [19] artikuluko 6. eta 7. ataletan morfogenesia aztertzeko eta hainbat emaitza ateratzeko erabili zituen kontzeptu eta baliabide matematiko batzuk bilduko ditugu: erreakzio-difusio ekuazioak, Fourierren serieak eta Taylor-en polinomioen bidezko funtzioen linealizazioa. Artikulua gehiegi luza ez dadin, ekuazio eta sistema diferentzialak eta horiek ebazteko ezagunak diren emaitzak zein teknikak gogoratzeko edota ulertzeko, bibliografian ageri den Ordinary Differential Equations liburura, [22], bideratuko dugu irakurlea.

\subsection{Erreakzio-difusio ekuazioak}

Erreakzio-difusio ekuazioak deribatu partzialetako ekuazio ez-linealak dira, eta, historikoki, horiek proposatzeko motibazio nagusia biologiako zenbait gai izan ziren, $[5,726$. or.] lanean aipatzen denaren arabera. XX. mendeko 40ko hamarkada baino lehen hasi ziren erabiltzen. Izan ere, Ronald A. Fisher estatistikaria eta biologoa izan zen ekuazio hauekin lanean hasi zen lehenengoetarikoa. Zientzialari horren xedea zen ezaugarri genetikoen espazioko hedapena deskribatzea. Horretarako, 1937an, difusio ekuazio ez-linealekin lanean hasi behar izan zuen, ordura arte planteatuta zegoen Malthus-en populazio-hazkuntzaren legea ez baitzen nahiko zehatza deskribatu nahi zuen egoera modelizatzeko. Aztergai izan zuen ekuazio ez-linealaren ezaugarri nagusia populazioaren hazkuntza mugatzen zuen osagaia izan zen.

50eko hamarkada hasi arte, banaka erabiltzen ziren erreakzio-difusio ekuazioak, baina 1952an, Turingek zein Hodgkin eta Huxley fisiologo eta biofisikari ingelesek erreakzio-difusio sistemak proposatu zituzten euren ikerketetan. Hodgkinek eta Huxleyek axoi ${ }^{7}$ baten barnean nerbio-bulkaden hedapena deskribatzeko planteatu zuten erreakzio-difusio ekuazioen sistema. Turingek animalien ilajeetan sortzen diren patroien eraketa azaldu

\footnotetext{
7 Neuronaren luzapena da, zeinetatik nerbio-bulkadak transmititzen baitira.
} 
nahirik erabili zituen, artikulu honetako 3. eta 4. ataletan ikusiko dugunez. Nahiz eta sistemen erabileraren helburua ezberdina izan, jatorri ezberdineko fenomenoak edota egoera konplexuagoak deskribatzeko sistemak erabiltzearen ideia iraultzailetzat hartu zen bi kasuetan. Horrez gain, gure artikuluko sarreran aurreratu dugun bezalaxe, Turingek erreakzio-difusio ekuazioak aztertzeko erabili zuen metodoa guztiz berria izan zen, 2.3. atalean azalduko dugunez, eta animalien ilajeetako patroien inguruko emaitza ikusgarriak lortu zituen.

Atal honetan, erreakzio-difusio ekuazioak eta horiek osatzen dituzten termino matematikoak izendatu eta azalduko ditugu. Hasteko, denboraeta espazio-aldagai jarraituetarako azalduko dugu. Ondoren, denbora-aldagai jarraitua baina espazio-aldagai diskretua duen egoera aztertuko dugu. Lehenengo kasua, artikulu honetako eraztun jarraituari dagokion 4. atala garatzeko erabiliko dugu, eta bigarren kasua, aldiz, eraztun diskretuko 3. atala garatzeko.

\subsubsection{Espazio- eta denbora-aldagai jarraituko erreakzio-difusio ekuazioak}

Kasu honetan erabiliko ditugun funtzio eta adierazpenetan, erreakziodifusio ekuazioak azaltzeko espazio- zein denbora-aldagaiak jarraituak direla onartuko dugu.

Izenak adierazten duen moduan, erreakzio-difusio ekuazioek erreakzioeta difusio-mekanismoak barnebiltzen dituzte. Bi prozesuak deskribatzeko, era honetako bigarren ordenako deribatu partzialetako ekuazio ez-homogeneoak erabiltzen dira:

$$
\frac{\partial u}{\partial t}(x, t)=f(u(x, t))+D(x) \Delta u(x, t),
$$

$u=u(x, t): \Omega \times(0, \infty) \rightarrow \mathbb{R}$ populazio baten dentsitatea, $D(x)$ populazioari dagozkion difusio-koefizienteekin osatutako matrizea eta $\Omega \subset \mathbb{R}^{n}$ eremu irekia izanik. $f$ funtzioak $u$ populazioan aldaketak eragiten dituzten prozesuak deskribatzen ditu, hala nola erreakzio kimikoak eta jaiotza- edo heriotza-tasak.

Gure kasuan, 3. eta 4. ataletan zehar landuko ditugun erreakzio-difusio ekuazioak substantzia kimikoekin lotuta egongo direnez, hona hemen ekuazioaren terminoen esanahi kimikoa:

$-u^{i}=u^{i}(x, t): \mathbb{R}^{3} \times(0, \infty) \rightarrow \mathbb{R} C^{2}$ klaseko funtzioak $x$ puntuko eta $t$ uneko $i$. substantziaren kontzentrazioa deskribatuko du, $i \in\{1, \ldots, m\}$ izanik. 
$-D^{i}(x)$ substantzien difusio-koefizienteen matrizea izango da, $i \in\{1, \ldots, m\}$ izanik.

$-D^{i}(x) \Delta u^{i}(x, t)$ gaia ${ }^{8}$ substantzien partikulen mugimenduaren (difusioaren) arduraduna izango da.

$-f^{i}\left(u^{1}, \ldots, u^{m}\right) i$. substantziaren erreakzio-funtzioa izango da, $i \in\{1, \ldots, m\}$ izanik. Hau da, partikulen arteko erreakzio kimikoaren mekanismoaren adierazlea izango da.

Ondorioz, gure kasuan, era honetan deskribatuko dugu zelulen arteko erreakzio-difusio prozesua:

$$
\frac{\partial u^{i}}{\partial t}(x, t)=f^{i}\left(u^{1}, \ldots, u^{m}\right)+D^{i}(x) \Delta u^{i}(x, t),
$$

$i \in\{1, \ldots, m\}$ izanik.

1. oharra. Artikuluan zehar, $D^{i}(x)$ konstantetzat hartuko dugu $\forall i \in\{1, \ldots, m\}$, Turingek [19] ikerlanean difusio-koefizienteak konstantetzat hartu baitzituen.

[4] eta [9] lanetan ikus daitekeenez, erreakzio-difusio ekuazioen eraketa-masaren kontserbazioaren legean, Fick-en lehenengo eta bigarren legeetan eta matematikako kalkulu eta analisi bektorialeko hainbat emaitzatan oinarritzen da.

\subsubsection{Espazio-aldagai diskretuko eta denbora-aldagai jarraituko erreakzio-difusio ekuazioak}

Orain, espazio-aldagaia diskretua deneko erreakzio-difusio ekuazioa azalduko dugu; hots, aurkeztu berri dugun eredua espazio-aldagaiarekiko diskretizatuko dugu. Dena den, hori aurkeztu baino lehen, diskretizazioprozesuaren oinarria deskribatuko dugu.

Nahiz eta agian ezin dugun zehazki jakin, Turingen ibilbidea aztertuta eta, besteak beste, problema biologikoak modelizatzeko erabili izan diren eredu diskretuen planteamenduen urteak ikusita, [13, sarrera], esan dezakegu eredu diskretuek artikulu honetako sarreran aipatu ditugun automata zelularretan $^{9}$ izan dezaketela jatorria. Izan ere, automata zelularrak eredu diskretu

${ }^{8} \Delta$ Laplaceren eragilea da. Adibide konkretu bat ematearren, $u: D \subset \mathbb{R}^{3} \rightarrow \mathbb{R}$ funtzioa $C^{2}(D)$ klasekoa bada, $\Delta u=\frac{\partial^{2} u}{\partial x^{2}}+\frac{\partial^{2} u}{\partial y^{2}}+\frac{\partial^{2} u}{\partial z^{2}}$ izango da.

9 Automata zelularrak definitu, garatu eta aztertu zituzten zientzialari ezagunen artean hauek ditugu: J.V. Neumann (ikus bere [12] liburua), K. Zuse, S.M. Ulam, J.H. Conway eta S. Wolfram. 
modura uler daitezke. Zelula-automatak espazioaren eta denboraren menpe daudenez, sistema dinamiko edo deribatu partzialetako ekuazio diskretu baten baliokideak dira (ikus [6, 4.1. atala]). Horrez gain, aipatzekoa da modelizazio egokiaren ikuspuntutik egokiak direla espazioarekiko diskretuak diren ekuazioak, aztertzen ari garen sistemaren eremua diskretua baita, [7].

Zenbakizko metodoak lagungarriak izango zaizkigu erreakzio-difusio ekuazioen diskretizazio-prozesuan. Horren arrazoia da egoera finituko automata zelularren eta diferentzia finituko zenbakizko metodoaren eskemen arteko antzekotasuna. Automata zelular baten egoera kopurua erlazionatuta dagoen diferentzia finituko ekuazioak duen egoera kopuruarekin konparagarria bada, orduan, emaitzak konparagarriak izatea espero da (ikus [14, 18.3.2. atala]).

(1) erreakzio-difusio ekuazioan espazio-aldagaia diskretizatzen badugu zenbakizko metodoen arloan ezaguna den bigarren ordenako diferentzia finitu zentraleko hurbilketa erabiliz ${ }^{10}$, denboraren aldagaia jarraitua mantenduta, eredu diskreturako erreakzio-difusio ekuazioa lortuko dugu.

Horretarako, (1) ekuazioa eratzeko erabilitako $\Omega$ eremua $N$ zati ${ }^{11}$ homogeneotan banatuko dugu, eta zati horien zentroak banatzen dituen $h$ distantzia konstantea definituko dugu. 3. ataleko eraztun diskretuaren kasuan, $\Omega \mathbb{R}^{2}$-ko eraztun bat izango da, eta $N$ zati homogeneoen zentroek zirkunferentzia bat eratuko dute, $h$ arku-luzera konstante bat izanik (ikus 1. irudia). $r \in\{1, \ldots, N\}$ zatia hartuta, $z_{r}=h r$ banatu ditugun zatien zentroak izango dira, $u_{r}^{i}(t):=u^{i}(h r, t) \Omega$-ren $r$ zatiko eta $t$ uneko $i$. substantziaren kontzentrazioa adieraziko du, eta $f_{r}^{i}=f^{i}\left(u_{r}^{1}, \ldots, u_{r}^{m}\right) r$ zatiko $i$. substantziaren erreakzio-funtzioa izango da, $i \in\{1, \ldots, m\}$ izanik.

Orain, espazio-aldagaia dimentsio bakarrekoa dela suposatuko dugu. Orduan, diferentzia finitu zentraleko hurbilketa erabiltzen badugu, honako hurbilketa hau izango dugu laplacetarrarentzat:

$$
\Delta u^{i}\left(z_{r}, t\right)=\frac{\partial^{2} u^{i}}{\partial z_{r}^{2}}\left(z_{r}, t\right) \approx \frac{u_{r+1}^{i}-2 u_{r}^{i}+u_{r-1}^{i}}{h^{2}} .
$$

Era horretan, (1) ekuazioaren bertsio diskretua (edo erreakzio-difusio ekuazio diskretua) honela adieraz dezakegu:

$$
\frac{\partial u_{r}^{i}}{\partial t}=f^{i}\left(u_{r}^{1}, \ldots, u_{r}^{m}\right)+\frac{D^{i}}{h^{2}}\left(u_{r+1}^{i}-2 u_{r}^{i}+u_{r-1}^{i}\right),
$$

$i \in\{1, \ldots, m\}$ eta $r \in\{1, \ldots, N\}$ izanik.

10 Zenbakizko metodo horiei buruz [2] liburuan aurkitu daiteke informazioa, adibidez.

${ }^{11}$ Elementu ere dei ditzakegu. Geuk, 3. atalean, zelula biologikoak direla onartuko dugu. 
2. oharra. Gure $\Omega$ eremuaren zatien zentroen arteko distantzia gero eta txikiagoa egiten badugu $(h \rightarrow 0)$, hau da, eremuaren zati kopurua handitzen badugu $(N \rightarrow \infty)$, eredu diskretutik jarraitura pasa gaitezke.

3. oharra. Azaldu berri ditugun erreakzio-difusio ekuazio orokorren ereduak (jarraitua eta diskretua) Turingek aurkeztu zituen [19] artikuluko 47. eta 49. orrialdeetan. Modelizazio orokor horiek artikulu honetako 3. eta 4. ataletan azalduko ditugun kasu partikularrekin konparatzen baditugu, erabiliko dugun notazioaren inguruan hau esan dezakegu:

(i) Turingek bi substantziekin jardun zuen, $u^{1}=X$ eta $u^{2}=Y$ izendatu zituenak.

(ii) 3. eta 4. ataletako erreakzio-difusio ekuazio diskretuak eta jarraituak erlazionatzen dituen konstantea $h=\frac{2 \pi \rho}{N}$ da; hau da, $\rho$ erradioko zirkunferentziaren perimetroa $N$ zatitan banatzean ateratzen den arku-luzera.

(iii) 3. eta 4. ataletan agertuko zaizkigun difusio-koefizienteak $\left(\mu, v, \mu^{\prime}\right.$ eta $\left.v^{\prime}\right)$ aurretik azaldu ditugun $\frac{D^{i}}{h^{2}}$ eta $D^{i}$ koefizienteak izango dira, $i \in\{1,2\}$ izanik. Gainera, difusio-koefizienteen artean honako erlazio hauek defini ditzakegu: $\mu=\frac{D^{1}}{h^{2}}=\frac{\mu^{\prime}}{h^{2}}$ eta $v=\frac{D^{2}}{h^{2}}=\frac{v^{\prime}}{h^{2}}$.

\subsection{Fourierren serieak}

XIX. mendearen hasieran, J. Fourier matematikari frantziarrak Fourierren serieen teoria gisa ezaguna den matematikako arloa garatu zuen, beroaren ekuazioa aztertzen ari zela. Fourierren analisia zenbait funtzio, hala nola uhinak edo seinaleak, sistema bateko funtzio ortogonalen konbinazio lineal gisa hurbiltzeko aukera ematen duen tresna matematiko bat da. Funtzio ortogonalen multzo hori egokiro aukeratuz, multzo horretako funtzioen ezaugarrien eta propietateen arabera egin daiteke aztergai den funtzioaren analisia. Fourierren analisiko oinarri-funtzioak sinusoideak ${ }^{12}$ dira; hots, anplitude, fase eta maiztasun zehatz batekin sinu gisa adieraz daitezkeen funtzioak.

${ }^{12}$ Sinusoideak bakarrik aipatu baditugu ere, aintzat hartu behar dugu kosinuak sinuen bidez adieraz ditzakegula. 
Turingek erabili zituen Fourierren serieetara gerturatzeko, lehenengo, aldagai jarraitu edo diskretu bakar baten menpe dauden funtzioen Fourierren serieak aurkeztuko ditugu. Ondoren, bi aldagai bananduko funtzioen serieen eraketaren arrazoiketa aurkeztuko dugu. Horrela, Turingek erabili zituen bi aldagai jarraitutarako zein aldagai diskretu eta aldagai jarraitu bikoterako serieak ulertzeko eta erabiltzeko gai izango gara 3. eta 4. atale$\tan$.

\subsubsection{Aldagai jarraituko Fourierren serieak}

Hasteko, $T \in \mathbb{R}$ periododuna den $f: \mathbb{R} \rightarrow \mathbb{C}$ funtzio jarraitu baten Fourierren seriezko garapena eta bere propietate bat aztertuko ditugu. Kontuan izan, $f T$ periododuna izanda, nahikoa dela Fourierren seriea $D=\left[-\frac{T}{2}, \frac{T}{2}\right] \subset \mathbb{R}$ erako tarte batean definitzea (Fourierren seriearen oinarrizko tarte gisa ezaguna dena). D tarteko eta $T$ periododun $f$ funtzioaren Fourierren seriezko garapen esponentzial konplexua hau da:

$$
f(x) \sim \sum_{s=-\infty}^{\infty} \exp \left(\frac{2 \pi i x s}{T}\right) C_{s},
$$

non $x \in D$ eta $C_{s}=\frac{1}{T} \int_{D} f(x) \exp \left(-\frac{2 \pi i s x}{T}\right) d x$ baitira, $s \in \mathbb{Z}$ izanik. $C_{s} \in \mathbb{C}$ koefizienteari $f$ funtzioaren Fourierren serie konplexu esponentzialaren koefiziente deritzo, $s \in \mathbb{Z}$ izanik. Bestalde, $\sim$ zeinuak $f$ funtzioak eskuineko seriea zehazten duela adierazten du, baina ez seriea konbergentea denik. Are gehiago, nahiz eta seriea konbergentea izan, gerta liteke $f$ funtziorantz konbergentea ez izatea. Funtzio bat sinusoideen batura gisa egokiro adierazi ahal izateko, izaera jakin bat eduki beharko du; esaterako, honako teorema honetan aurkeztuko duguna.

1. teorema. (Dirichlet-en baldintzak). Demagun

(i) $f$ funtzioa zatika jarraitua dela $[a, b] \subset \mathbb{R}$ tartean,

(ii) $f$ funtzioa $T=b-a$ periododuna dela,

(iii) $f$ funtzioak mutur kopuru finitua duela $[a, b]$ tartean.

Orduan, $f$ funtzioari elkartutako Fourierren seriea, (3), konbergentea da $f$ funtziorantz $\mathbb{R}$-n eta $\forall x \in \mathbb{R} f(x)=\frac{f\left(x^{+}\right)+f\left(x^{-}\right)}{2}$ da, non $f\left(x^{+}\right)=\lim _{y \rightarrow x^{+}} f(y)$ eta $f\left(x^{-}\right)=\lim _{y \rightarrow x^{-}} f(y)$ adierazten baitute. 
4. oharra. Oro har, zientzian eta ingeniaritzan aztertzen eta deskribatzen diren egoeretan, Dirichleten baldintzak betetzen dituzten funtzioak ageri dira, [16, 23. or.]. Hortaz, 4. atalean kimikako egoera bat deskribatuko dugunez, $f$ funtzioak Dirichleten baldintzak beteko dituela onar dezakegu.

\section{5. oharra.}

(i) $\left\{\exp \left(\frac{2 \pi i s x}{T}\right): s \in \mathbb{Z}\right\}$ sistema ortogonalada $\langle f, g\rangle=\int_{D} f(t) \cdot \overline{g(t)} d t$ biderkadurarekiko $L^{2}(D)=\left\{f: \mathbb{R} \rightarrow \mathbb{C}: \int_{D}|f(x)|^{2} d x<\infty\right\}$ espazioan.

(ii) Ortogonala den edozein sistema linealki askea da.

\subsubsection{Aldagai diskretuko Fourierren serieak}

Aurkeztu dugun Fourierren seriezko garapena aldagai jarraituetarako eman dugu, baina zer gertatzen da aldagaia diskretua den kasuetan? Egoera horiek erabat interesgarriak dira egunerokotasunean; izan ere, egiten diren neurketak finituak dira. Hau da, puntu kopuru finituek osatzen dute funtzioen eremua. Horrez gain, kasu batzuetan, batura finitu batekin nahikoa izaten da aztertzen den funtzio periodikoaren hurbilketa onargarri ${ }^{13}$ bat emateko.

Izan bedi $N \in \mathbb{N}$ periododuna den $f: \mathbb{N} \rightarrow \mathbb{C}$ funtzioa. Funtzioa $N$ periododuna izanda, nahikoa da Fourierren seriea $\{1,2,3, \ldots, N\}$ erako multzo batean definitzea. Orduan, hau da $f$-ren Fourierren Serie Diskretua ${ }^{14}$ :

$$
f(r)=\sum_{s=0}^{N-1} \exp \left(\frac{2 \pi i r s}{N}\right) C_{s}
$$

non $r \in\{1,2,3, \ldots, N\}$ eta $C_{s}=\frac{1}{N} \sum_{r=1}^{N} f(r) \exp \left(-\frac{2 \pi i s r}{N}\right)$ baitira $s \in\{0, \ldots, N-1\}$ izanik.

Fourierren serie diskretuen atalarekin bukatzeko, eraztun diskretuei buruzko 3. atalean erabiliko dugun lema ${ }^{15}$ hau enuntziatuko dugu.

\footnotetext{
13 Ezartzen den zehaztasunaren araberakoa.

${ }^{14}$ Fourierren Transformatu Diskretua ere esaten zaio. Turingek [19, (6.3)]-n aurkeztu zituen adierazpenen forma orokorra, hain zuzen ere.

15 1. lemaren froga $[21,26 .-27$. or.] lanean aurki daiteke, adibidez.
} 
1. lema. Izan bedi $N \in \mathbb{N}$. Orduan, $l \in\{0, \ldots, N\}$ izanik,

$$
\sum_{r=1}^{N} \exp \left(\frac{2 \pi i l r}{N}\right)=\left\{\begin{array}{l}
N, l=0 \text { edo } l=N \text { denean } \\
0, \text { beste kasuetan }
\end{array}\right.
$$

\subsubsection{Bi aldagaiko Fourierren serieak}

Puntu honetara arte txertatu ditugun emaitzak aldagai bakarreko funtzioei dagozkien emaitzak dira, baina zer gertatzen da aldagai anitzeko funtzioekin lan egin nahi badugu? Nola heda dezakegu Fourierren serieen definizioa bi aldagaiko funtzioetara?

Hasteko, bi aldagai jarraitutarako Fourierren seriea nola uler daitekeen azaldu eta zehazki adieraziko dugu. Alde batetik, $t$-ren balioa finkatzen badugu, $F(x, t)$ funtzioa $x$-ren menpeko funtzio gisa uler daiteke. Bestetik, $x$ aldagaiaren menpeko funtzioa Fourierren serie bidez adieraz badaiteke,

$$
F(x, t)=\sum_{s=-\infty}^{\infty} \exp \left(\frac{2 \pi i x s}{T}\right) C_{s}
$$

ziurta dezakegu. Horrez gain, kontuan izanda denbora aurrera joan ahala $C_{s}$ koefizienteak denboraren arabera aldatzen direla, $F$ funtziorako garapen hau eman dezakegu:

$$
F(x, t)=\sum_{s=-\infty}^{\infty} \exp \left(\frac{2 \pi i x s}{T}\right) C_{s}(t)
$$

Espazioko aldagaia diskretua bada, eman berri dugun azalpena dagokion (4) serie diskretuan erabiliz, $r$ aldagaiarekiko $N$ periododuna den eta denborarekiko jarraitua den $F$ funtziorako hau lortuko dugu:

$$
F(r, t)=\sum_{s=0}^{N-1} \exp \left(\frac{2 \pi i r s}{N}\right) C_{s}(t)
$$

\section{6. oharra.}

(i) Serie infinituek aukera emango digute eraztun jarraituak aztertzeko; hots, zelula kopuru infinituz osatutako ehunak aztertzeko. Zelula isolatuen bildura gisa funtzionatzen duten eraztunetarako, diskretuetarako, eraztun jarraituen sinplifikazioak direnez, aipatu ditugun serie diskretuak erabiliko ditugu. 
(ii) 3. eta 4. ataletako substantzien kontzentrazioetan dauden perturbazioak ${ }^{16}$ Fourierren serie hauen bidez hurbilduko ditugu:

a) Eraztun diskretuetan, funtzioak $\mathrm{r}$ aldagaiarekiko $N$ periododunak direnez, honela adieraziko ditugu perturbazioak $\forall(r, t) \in\{1, \ldots, N\} \times(0, \infty)$ :

$$
x(r, t)=\sum_{s=0}^{N-1} \exp \left(\frac{2 \pi i r s}{N}\right) \xi_{s}(t) \quad \text { eta } \quad y(r, t)=\sum_{s=0}^{N-1} \exp \left(\frac{2 \pi i r s}{N}\right) \eta_{s}(t) .
$$

b) Eraztun jarraituetan, aldiz, funtzioak $\theta$ aldagaiarekiko $2 \pi$ periododunak izanda, honela adieraziko ditugu perturbazioak $\forall(\theta, t) \in[0,2 \pi] \times(0, \infty)$ :

$$
\begin{aligned}
& x(\rho, \theta, t)=\sum_{s=-\infty}^{\infty} e^{i \theta s} G_{s}(t) \quad \text { eta } \quad y(\rho, \theta, t)=\sum_{s=-\infty}^{\infty} e^{i \theta s} H_{s}(t), \\
& \text { non } \rho \in\left(\rho_{1}, \rho_{2}\right) \text { baita. }
\end{aligned}
$$

Atal honetan erakutsitako Fourierren serieei buruz gehiago irakurtzeko, [8], [17] eta [21] bibliografiara bideratzen dugu interesatuta dagoen irakurlea.

\subsection{Funtzioen linealizazioa}

Ekuazio ez-linealak ebazteko, askotan, ekuazio horren hurbilketa lineal bat lortzea da bidea. Horrek jatorrizko ekuazioa errazteko aukera ematen du, ez-lineala den ekuazio bat ekuazio lineal baten bidez hurbil dezakegulako, baina ez edonola. Ekuazioak linealizatzeko modua Taylorren seriezko garapenak erabiltzea da. Hala ere, kontuan izan behar dugu linealizazioa ez dela edozein punturen inguruan egin behar, hurbilketa ahalik eta zehatzena izatea nahi baitugu. Linealizazioa definituko dugun oreka-puntuaren ${ }^{17}$ inguruan egiten bada, erreakzio-difusio ekuazio ez-linealak ekuazio linealetatik gertu $^{18}$ egongo dira, eta esplizituki ebatzi ahal izango dira soluzioen lehenengo hurbilketak lortzeko. Gainera, egoera horretan, linealizazioaren errorea minimo egingo da sistemaren soluzio guztietarako.

Oreka-puntuaren definizioa eman aurretik, Turingek [19] artikuluan erreakzio-difusio ekuazioak aztertzeko jarraitu zuen ideia iraultzailea azalduko dugu, bere lanaren garrantzia goraipatzen duena, beste behin. Turin-

\footnotetext{
16 Perturbazioek sistema oreka-puntutik aldentzea eragingo dute.

17 Eragiketa- edo linealizazio-puntu ere esaten zaio.

18 Zehaztasun terminoetan.
} 
gek difusiorik gabe egonkorra den sistema bat difusioarekin ezegonkor ${ }^{19}$ bihur zitekeela erakutsi zuen; eta, horrela, animalien ilajeetan patroiak sor zitezkeela. Ideia hori beste zientzialari batzuentzat burugabekeria zen. Izan ere, duela 70 urteko fisikariek difusioa sistema homogeneizatzen zuen termino egonkor bat zela pentsatzen zuten, eta, horregatik, difusioaren terminoa sisteman sartzea eta emaitza interesgarriak lortzea ideia bateraezinak iruditzen zitzaizkien. Guk dakigunera arte, testuinguru horretan Turing izan zen difusioa interesgarria zela antzeman zuen lehenengo ikerlaria.

Turingek erreakzio-difusio sistemak aztertzeko erabili zuen era [19] artikuluko «Reactions and Diffusion in a Ring of Cells» eta «Continuous Ring of Tissue» ataletan dago: lehen pausoan, erreakzio-difusio sisteman difusio terminoa kentzen da eta linealizazioa difusiorik gabeko sistemaren oreka-puntu batean egiten da, gure artikuluko 3. eta 4. ataletan ikusiko dugun bezalaxe. Horregatik, oreka-puntuaren hurrengo definizioa ekuazio diferentzialetako sistema orokor baterako eman arren, gure analisietan difusiorik gabeko sistemetan erabiliko dugu.

1. definizioa. Izan bitez $\vec{x}: I \subset \mathbb{R} \rightarrow \mathbb{R}^{m} C^{1}(I)$ klaseko funtzioa, $\vec{x}(t)=\left(x_{1}(t), \ldots, x_{m}(t)\right)$ izanik, eta $f: D \subset \mathbb{R}^{m} \rightarrow \mathbb{R}^{m}$ funtzio jarraitua $D$ multzoan, $\vec{x}(I) \subset D$ izanik. Orduan, $\vec{x}_{0} \in D \vec{x}^{\prime}=f(\vec{x}) m$ ekuazio diferentzialetako sistemaren oreka-puntua dela diogu $f\left(\vec{x}_{0}\right)=0$ betetzen badu, non $\vec{x}^{\prime}(t)=\left(x_{1}^{\prime}(t), \ldots, x_{m}^{\prime}(t)\right)$ baita.

\section{7. oharra.}

(i) Oreka-puntu bat egonkorra dela esaten da, perturbazio txikien ostean, oreka-puntutik gertu dauden sistemaren soluzioak denboran zehar oreka-puntutik gertu mantentzen baldin badira. Oreka-puntu bat ezegonkorra dela esaten da, perturbazio txikien ostean, oreka-puntutik gertu dauden sistemaren soluzioak denboran zehar puntu horretatik aldentzen baldin badira.

(ii) Sistema bat egonkorra edo ezegonkorra dela esaten da, bere oreka-puntua holakoa bada.

Orain, linealizazioa oreka-puntuaren inguruan egitearen arrazoia azalduko dugu. Izan bitez $C^{\infty}(D)$ klasekoa den $f: D \subset \mathbb{R}^{n} \rightarrow \mathbb{R}$ funtzioa, $\vec{x}_{0}=\left(x_{0_{1}}, \ldots, x_{0_{n}}\right)$ horren oreka-puntua eta $\vec{x}=\left(x_{1}, \ldots, x_{n}\right) \in \mathbb{R}^{n} \vec{x}_{0}$-tik gertu dagoen puntu bat. Orduan, Taylorren seriezko $f$ funtzioaren $\vec{x}_{0}$ puntuaren inguruko hurbilketa honako hau da:

${ }^{19}$ Ikus 7. oharra, sistema egonkor eta ezegonkorrei buruz jakiteko. 


$$
f(\vec{x})=f\left(\vec{x}_{0}\right)+\sum_{j=1}^{n} \frac{\partial f\left(\vec{x}_{0}\right)}{\partial x_{j}}\left(x_{j}-x_{0_{j}}\right)+\varepsilon,
$$

non $\varepsilon$ hondarra baita. Hondarrak Taylorren serieari dagozkion $k \geq 2$ ordenako gai baztergarriak biltzen ditu. Izan ere, $\vec{x}$ oreka-puntutik gertu dagoen puntua denez, $\vec{x}-\vec{x}_{0}$ txikia izango da eta horren berreturak are txikiagoak. (5) garapeneko koefizienteak, $\frac{\partial f\left(\vec{x}_{0}\right)}{\partial x_{j}}$, linealizazio-puntuaren menpekoak dira; ikus $[19,47$. or. $]$.

Turingek bi morfogeneren kontzentrazioak aldagaitzat zituzten funtzioak erabili zituenez, demagun bi aldagaiko funtzioak ditugula aztergai. Horrez gain, demagun bi ekuazio diferentzialetako sistema edo deribatu partzialetako sistema bat dugula, zeinetan $f(x, y)$ eta $g(x, y)$ funtzio ez-linealak ageri baitira (ekuazio bakoitzean bat), eta suposa dezagun $(h, k)$ sistemaren oreka-puntua dela. Turingek jarraian adieraziko dugun moduan definitu zituen aipatu berri ditugun linealizazio-koefizienteak, [19, 47. or.].

2. definizioa. Demagun $(h, k)$ aztergai dugun sistemaren oreka-puntu bat dela. Orduan, $a, b, c$ eta $d$ bazterreko erreakzio-tasak honela definitzen ditugu, hurrenez hurren: $\frac{\partial f}{\partial x}(h, k) \frac{\partial f}{\partial y}(h, k) \frac{\partial g}{\partial x}(h, k)$ eta $\frac{\partial g}{\partial y}(h, k)$. Bazterreko erreakzio-tasak elementutzat dituen matrizeari, hots, $f$ eta $g$ funtzioen $(h, k)$ puntuko matrize jakobiarrari, bazterreko erreakzio-tasen matrizea esaten diogu.

Beraz, honela adieraz ditzakegu $f$ eta $g$ funtzioak Taylorren seriezko garapenaren bidez $(h, k)$ oreka-puntuaren ingurunean, $(x, y)$ puntua orekapuntutik gertu dagoen puntu baterako:

$$
\left\{\begin{array}{l}
f(x, y)=f(h, k)+\frac{\partial f(h, k)}{\partial x}(x-h)+\frac{\partial f(h, k)}{\partial y}(y-k)=a(x-h)+b(y-k) \\
g(x, y)=g(h, k)+\frac{\partial g(h, k)}{\partial x}(x-h)+\frac{\partial g(h, k)}{\partial y}(y-k)=c(x-h)+d(y-k)
\end{array} .\right.
$$

\section{ERAZTUN DISKRETUKO GARAPEN MATEMATIKOA}

Zelulak zenbait modutan antola daitezke, eta, beraz, forma bat baino gehiago era ditzakete. Antolaketa horiek oso konplexuak izatera hel daitezke, 
eta horrek tratamendu matematikoa zailtzen du. Horregatik, Rashevskyk [15] artikuluan idatzi zuen moduan: errealitateko egoerak matematikoki azaltzeko, ezinbestekoa da egoera sinpleenetik hastea, hots, idealizatuenetik.

Horixe bera izan zen Turingek morfogenesiaren prozesua ulertzen saiatzeko egin zuena. Sinplea den eta printzipio orokorrak azaltzeko aukera ematen duen antolaketa zehatz bat hautatu zuen lehenengo erreakzio-difusio eredua eraikitzeko: antzekoak diren zelula bananduez osatutako eraztun laua; eraztun diskretua, alegia. Kontuan izan behar dugu ez dagoela planteatu zuen lehenengo eredu horrekin bat datorren adibide biologiko "gordinik». Izan ere, arrazoi bat aipatzearren, bi dimentsiotako eraztuna erabili zuen, eta zelulak meheak badira ere, bolumena dute.

Atal honetan, Turingek [19] artikuluko 6. atalean («Reactions and Diffusion in a Ring of Cells» izenburupean) bildu zituen azalpen eta garapen matematikoak aztertu, garatu eta justifikatuko ditugu. Hasteko, Turingek eraztun diskreturako planteatu zuen bi morfogeneren ekuazio-sistema aztertu; eta, ostean, 2.2. atalean aipatu ditugun Fourierren serieez baliatuta, sistema sinplifikatuko eta ebatziko dugu. Turingek egindako ikerketari jarraituz, guk ere bi morfogenerekin lan egingo dugu.

\subsection{Eraztun diskretuaren deskribapena}

Eman diezaiogun aipatutako zelula bananduez osatutako eraztunari deskribapen matematikoa. Izan bedi $N \in \mathbb{N}$ zelulaz osatutako $L$ eraztuna ${ }^{20}$, beheko 1 . irudian ikus daitekeenaren antzekoa. $L$ eraztunak $N$ zelula kopuru finitua duenez, muga-baldintza bakarra zehaztu beharko dugu.

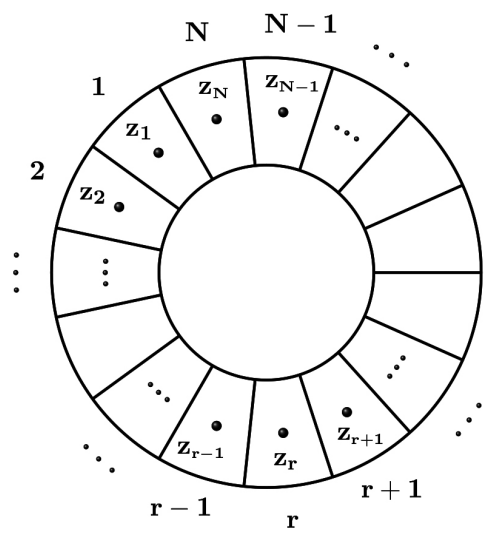

1. irudia. $N$ zelulaz osatutako $L$ eraztuna.

20 Turingek 20 zelulaz osatutako eraztun baterako zenbakizko adibide esperimental bat aurkeztu zuen, [19, 10. atala]. 
Demagun muga-baldintza hori periodikoa dela: $N$ zelulaz osatutako sekuentzia etengabe errepikatzen dela onartuko dugu, $(N+1)$. zelula $\equiv 1$. zelula onetsiko dugu. Zelulak identifikatzeko, horiek eraztunean duten posizioa erabiliko dugu, $r \in\{1, \ldots, N\}$, hasierako zelula bat erreferentzia gisa hartuta. Horrez gain, zelulen espazioko erlazioak zehaztu behar ditugu bakoitzaren ingurune hurbileko konexioak aztertuta. Horretarako, zelulen koordinazio-zenbakia, $r$ zelularen ingurune hurbila eta interakzio-ingurunea definitu behar ditugu.

3. definizioa. Zelula batekin konektatuta dauden zelula kopuruari koordinazio-zenbaki deritzogu, eta $b$ letraren bidez adierazten da.

4. definizioa. $r$ zelula batekin konektatuta dagoen zelula multzoari $r$ zelularen ingurune hurbila deritzogu, eta $N_{b}(r)$ bidez adierazten da.

5. definizioa. $r$ zelularen egoeran eragina duen zelula-sareari $r$ zelularen interakzio-ingurunea deritzogu, eta $N_{b}^{\prime}(r)$ bidez adierazten da.

Kontuan izanda $r$ zelulak $r+1$ eta $r-1$ zelulekin egiten duela substantzien trukea, hau da deskribatu berri dugun $L$ eraztuneko $r$ zelularen ingurune hurbileko informazioa:

$$
b=2, N_{2}(r)=\{r-1, r+1\} \text { eta } N_{2}^{\prime}(r)=\{r-1, r, r+1\}, r \in\{1, \ldots, N\}
$$
izanik.

Demagun aztergai ditugun bi morfogeneak $X$ eta $Y$ direla, eta horien kontzentrazioak $X_{r}=X(r, t)$ eta $Y_{r}=Y(r, t)$ direla $^{21}$, hurrenez hurren, $t$ denboraren aldagaia izanik.

Automata zelularraren dinamika zehazteko, hots, zelulen egoera berriak determinatzeko, trantsizio-arauak behar ditugu. Definitu dugun eraztunean, substantziek, kontzentrazio-egoera aldatzeko, substantzien partikulen mugimendu naturalari jarraituko diote arau gisa, betiere, interakzio-ingurunea aintzat hartuta. Substantzien hedapen-tasek ez dute zertan berdinak izan; horregatik, zelulen arteko difusio-koefizienteak parametro ezberdinekin adieraziko ditugu. Demagun $X$ eta $Y$ substantzien difusio-koefizienteak, $\mu$ eta $v$, konstanteak direla; ikus 2.1. ataleko 3. oharra.

Deskribatzen ari garen sisteman difusioaz gain erreakzioa ere badagoenez, ezinbestekoa da $X$ eta $Y$ substantzien kontzentrazio-aldakuntzak definitzea; demagun $f$ eta $g$ direla, hurrenez hurren. Funtzio horiek erreakzio zinetiko gisa ezagutzen dira.

\footnotetext{
${ }^{21}$ Notazioa sinplifikatzearren, atal honetan erabiliko dugun $r$ 2.1. atalean adierazi dugun $z_{r}$ izango da (begiratu 1. irudia); hots, zelularen zentroa izango dela ulertuko dugu. $X_{r}$ eta $Y_{r} r$. zelularen zentroan dauden $X$ eta $Y$ morfogeneen kontzentrazioak izango dira, hurrenez hurren.
} 
Aipatutako guztia kontuan hartuta, zelula bakoitzean $X$ eta $Y$ morfogeneen kontzentrazioen aldaketak azaltzen dituen ekuazio diferentzialetako sistema diskretu hau defini dezakegu:

$$
\left\{\begin{array}{c}
\frac{d X_{r}}{d t}=f\left(X_{r}, Y_{r}\right)+\mu\left(X_{r+1}-2 X_{r}+X_{r-1}\right) \\
\frac{d Y_{r}}{d t}=g\left(X_{r}, Y_{r}\right)+v\left(Y_{r+1}-2 Y_{r}+Y_{r-1}\right)
\end{array},\right.
$$

ikus 2.1. ataleko (2) adierazpena.

Ekuazio diferentzialetako (6) sistema ebazteko, koefiziente konstantedun ekuazio diferentzial linealen sistema bihurtuko dugu; horretarako, linealizazioaren prozesua erabiliko dugu. Demagun sistemak oreka-puntu bat duela $(h, k)$ puntuan ${ }^{22}$, non $X_{r}$ eta $Y_{r}$ morfogeneen kontzentrazioen banaketak guztiz uniformeak baitira. Oreka-puntuaren osagaiak arinki aldatuta, $f\left(X_{r}, Y_{r}\right)$ eta $g\left(X_{r}, Y_{r}\right)$ linealtzat jo ditzakegu, $f$ eta $g$ funtzioak orekapuntuaren inguruan ebaluatzen ari baikara (ikus 2.3. azpiatala). Hau da, $f$ eta $g$ funtzio linealen bidez hurbil ditzakegu $(h, k)$ puntuaren inguruan:

$$
\left\{\begin{array}{l}
f\left(X_{r}, Y_{r}\right)=f\left(h+x_{r}, k+y_{r}\right)=a x_{r}+b y_{r} \\
g\left(X_{r}, Y_{r}\right)=g\left(h+x_{r}, k+y_{r}\right)=c x_{r}+d y_{r}
\end{array},\right.
$$

non $a, b, c$ eta $d$ parametroak bazterreko erreakzio-tasak ${ }^{23}$ baitira, eta $x_{r}$ zein $y_{r}$ jatorrizko kontzentrazioen gorabeherak. Demagun $x_{r}$ eta $y_{r} r$ eta $t$ aldagaien menpeko ausazko gorabeherak direla, $(r, t) \in\{1, \ldots, N\} \times(0, \infty)$ izanik. Aurrekoaren ondorioz, (6) sistema honela berridatz dezakegu:

$$
\left\{\begin{array}{l}
\frac{d x_{r}}{d t}=a x_{r}+b y_{r}+\mu\left(x_{r+1}-2 x_{r}+x_{r-1}\right) \\
\frac{d y_{r}}{d t}=c x_{r}+d y_{r}+v\left(y_{r+1}-2 y_{r}+y_{r-1}\right)
\end{array},\right.
$$

$r \in\{1, \ldots, N\}$ izanik.

$L$ eraztunari muga-baldintza ezarri diogunez, $x_{r}$ eta $y_{r}$ funtzioak $r$ aldagaiarekiko funtzio periodikoak izango dira. Gainera, 2.2. azpiatalean serie

\footnotetext{
${ }^{22}$ Gogoratu, 2.3. atalean azaldu dugun bezala, difusiorik gabeko ekuazioan oreka-puntu egonkorrak aztertu zituela Turingek, difusioa gehitzean ezegonkor bihurtuko zirenak.

${ }^{23}$ Ikus 2.3. azpiataleko 2. definizioa.
} 
diskretuen inguruan aipatutakoa betetzen dela suposatzen badugu, honako hau ziurta dezakegu:

$$
x_{r}=\sum_{s=0}^{N-1} \exp \left(\frac{2 \pi i r s}{N}\right) \xi_{s}(t) \quad \text { eta } \quad y_{r}=\sum_{s=0}^{N-1} \exp \left(\frac{2 \pi i r s}{N}\right) \eta_{s}(t)
$$

$r \in\{1, \ldots, N\}$ izanik.

Bestalde, $x_{r}$ eta $y_{r}$-ren adierazpenak (7) sisteman ordezkatu ahal izateko, $\xi_{s}(t)$ zein $\eta_{s}(t)$ koefizienteei deribagarriak izatea ezarri behar diegu.

Ordezka ditzagun orain (8)-ko $x_{r}$ eta $y_{r}$ adierazpenak (7) sisteman, eta sinplifika ditzagun ekuazioak. Prozesua berdina denez (7) sistemako bi ekuazioentzat, garapen errepikatuak ekidin nahian, (7) sistemaren lehenengo ekuazioarentzat egingo dugu analisia, eta bigarren ekuazioaren emaitza zuzenean jarriko dugu. Has gaitezen $\frac{d x_{r}}{d t}$-ri dagokion ekuazio bakoitzean $(r \in\{1, \ldots, N\}) x_{r}$ eta $y_{r}$ funtzioen Fourierren seriezko adierazpenak honela ordezkatzen:

$$
\begin{aligned}
\frac{d x_{r}}{d t}= & \frac{d}{d t}\left(\sum_{s=0}^{N-1} \exp \left(\frac{2 \pi i r s}{N}\right) \xi_{s}(t)\right)=a \sum_{s=0}^{N-1} \exp \left(\frac{2 \pi i r s}{N}\right) \xi_{s}(t)+b \sum_{s=0}^{N-1} \exp \left(\frac{2 \pi i r s}{N}\right) \eta_{s}(t) \\
& +\mu\left(\sum_{s=0}^{N-1} \exp \left(\frac{2 \pi i(r+1) s}{N}\right) \xi_{s}(t)-2 \sum_{s=0}^{N-1} \exp \left(\frac{2 \pi i r s}{N}\right) \xi_{s}(t)\right. \\
& \left.\quad+\sum_{s=0}^{N-1} \exp \left(\frac{2 \pi i(r-1) s}{N}\right) \xi_{s}(t)\right) \\
= & a \sum_{s=0}^{N-1} \exp \left(\frac{2 \pi i r s}{N}\right) \xi_{s}(t)+b \sum_{s=0}^{N-1} \exp \left(\frac{2 \pi i r s}{N}\right) \eta_{s}(t) \\
& +\mu \sum_{s=0}^{N-1} \exp \left(\frac{2 \pi i r s}{N}\right)\left[\exp \left(\frac{2 \pi i s}{N}\right)-2+\exp \left(-\frac{2 \pi i s}{N}\right)\right] \xi_{s}(t) .
\end{aligned}
$$

Bestalde, Eulerren formula erabiliz, hau dugu:

$$
\begin{aligned}
\exp \left(\frac{2 \pi i s}{N}\right)-2+\exp \left(-\frac{2 \pi i s}{N}\right) & =2 \cos \left(\frac{2 \pi s}{N}\right)-2=-2\left(1-\cos \left(\frac{2 \pi s}{N}\right)\right) \\
& =-4 \sin ^{2}\left(\frac{\pi s}{N}\right) .
\end{aligned}
$$


Ondorioz, (9) ekuazio-sistema honela berridatz dezakegu deribatuen erregela aplikatuta $r \in\{1, \ldots, N\}$ bakoitzerako:

$$
\sum_{s=0}^{N-1} \exp \left(\frac{2 \pi i r s}{N}\right) \frac{d \xi_{s}}{d t}=\sum_{s=0}^{N-1} \exp \left(\frac{2 \pi i r s}{N}\right)\left[\left(a-4 \mu \sin ^{2}\left(\frac{\pi s}{N}\right)\right) \xi_{s}+b \eta_{s}\right] .
$$

Har dezagun $s \in\{0, \ldots, N-1\}$ espazioko maiztasun jakin bat, dei diezaiogun $s^{\prime}$ eta biderka ditzagun (10) ekuazio-sistemako ekuazio bakoitzaren bi aldeak $e^{-\frac{2 \pi i r s^{\prime}}{N}}$ gaiarekin,

$$
\sum_{s=0}^{N-1} \exp \left(\frac{2 \pi i r\left(s-s^{\prime}\right)}{N}\right) \frac{d \xi_{s}}{d t}=\sum_{s=0}^{N-1} \exp \left(\frac{2 \pi i r\left(s-s^{\prime}\right)}{N}\right)\left[\left(a-4 \mu \sin ^{2}\left(\frac{\pi s}{N}\right)\right) \xi_{s}+b \eta_{s}\right]
$$

Aztergai dugun (11) sistemako ekuazio guztiak batzen baditugu (hau da, $r=1$ ekuaziotik $r=N$ ekuaziora bitarteko ekuazio oro gehituta), honako adierazpen hau lortuko dugu:

$$
\begin{aligned}
& \sum_{r=1}^{N} \sum_{s=0}^{N-1} \exp \left(\frac{2 \pi i r\left(s-s^{\prime}\right)}{N}\right) \frac{d \xi_{s}}{d t} \\
& =\sum_{r=1}^{N} \sum_{s=0}^{N-1} \exp \left(\frac{2 \pi i r\left(s-s^{\prime}\right)}{N}\right)\left[\left(a-4 \mu \sin ^{2}\left(\frac{\pi s}{N}\right)\right) \xi_{s}+b \eta_{s}\right]
\end{aligned}
$$

Aurreko adierazpeneko bi batukariak finituak direnez, elkarren artean truka ditzakegu:

$$
\begin{aligned}
& \sum_{s=0}^{N-1} \sum_{r=1}^{N} \exp \left(\frac{2 \pi i r\left(s-s^{\prime}\right)}{N}\right) \frac{d \xi_{s}}{d t} \\
& =\sum_{s=0}^{N-1} \sum_{r=1}^{N} \exp \left(\frac{2 \pi i r\left(s-s^{\prime}\right)}{N}\right)\left[\left(a-4 \mu \sin ^{2}\left(\frac{\pi s}{N}\right)\right) \xi_{s}+b \eta_{s}\right] .
\end{aligned}
$$

Hurrengo urratsa emateko, (12) ekuazioko ezkerreko adierazpena garatuko dugu soilik, eskuineko adierazpeneko garapena horren analogoa baita. Bestalde, $s, s^{\prime} \in\{0, \ldots, N-1\}$ direnez, $\left(s-s^{\prime}\right) \in\{0, \pm 1, \ldots, \pm(N-1)\}$ dugu, eta 1. lema erabiliz, hau lortzen da: 


$$
\begin{aligned}
\sum_{s=0}^{N-1} \sum_{r=1}^{N} \exp \left(\frac{2 \pi i r\left(s-s^{\prime}\right)}{N}\right) \frac{d \xi_{s}}{d t} & \\
= & \sum_{r=1}^{N} \exp \left(\frac{2 \pi i r\left(0-s^{\prime}\right)}{N}\right) \frac{d \xi_{0}}{d t}+\ldots+\sum_{r=1}^{N} \exp \left(\frac{2 \pi i r\left(s^{\prime}-s^{\prime}\right)}{N}\right) \frac{d \xi_{s^{\prime}}}{d t} \\
& +\ldots+\sum_{r=1}^{N} \exp \left(\frac{2 \pi i r\left(N-1-s^{\prime}\right)}{N}\right) \frac{d \xi_{N-1}}{d t} \\
= & 0 \frac{d \xi_{0}}{d t}+\ldots+N \frac{d \xi_{s^{\prime}}}{d t}+\ldots+0 \frac{d \xi_{N-1}}{d t}=N \frac{d \xi_{s^{\prime}}}{d t} .
\end{aligned}
$$

Hortaz, (12) adierazpenean $N$ sinplifikatuz, hau lortzen da:

$$
\frac{d \xi_{s^{\prime}}}{d t}=\left(a-4 \mu \sin ^{2}\left(\frac{\pi s^{\prime}}{N}\right)\right) \xi_{s^{\prime}}+b \eta_{s^{\prime}} \quad \forall s^{\prime} \in\{0, \ldots, N-1\} .
$$

Prozesu antzeko bat erabiliz, $y_{r}$-ren deribaturako honako adierazpen hau lortuko dugu:

$$
\frac{d \eta_{s^{\prime}}}{d t}=c \xi_{s^{\prime}}+\left(d-4 v \sin ^{2}\left(\frac{\pi s^{\prime}}{N}\right)\right) \eta_{s^{\prime}} \quad \forall s^{\prime} \in\{0, \ldots, N-1\} .
$$

Beraz, $\xi_{s^{\prime}}(t)$ eta $\eta_{s^{\prime}}(t)$ erabiliz, (7) sistema koefiziente konstanteak dituen ekuazio diferentzial linealen sistema honen bidez adieraz dezakegu:

$$
\left\{\begin{array}{c}
\frac{d \xi_{s^{\prime}}}{d t}=(a-\mu U) \xi_{s^{\prime}}+b \eta_{s^{\prime}} \\
\frac{d \eta_{s^{\prime}}}{d t}=c \xi_{s^{\prime}}+(d-v U) \eta_{s^{\prime}}
\end{array}\right.
$$

non $s^{\prime} \in\{0, \ldots, N-1\}$ eta $U=\left(2 \sin \left(\frac{\pi s^{\prime}}{N}\right)\right)^{2}$ baitira. Orotara, $N$ sistema ditugu, espazioko $s^{\prime}$ maiztasun bakoitzeko sistema bat baitaukagu.

Sistemaren soluzioak lortzeko, (13) sistemaren era matrizialarekin lan egingo dugu, 
$\left(\begin{array}{c}\frac{d \xi_{s^{\prime}}}{d t} \\ \frac{d \eta_{s^{\prime}}}{d t}\end{array}\right)=A\left(\begin{array}{c}\xi_{s^{\prime}} \\ \eta_{s^{\prime}}\end{array}\right)$ sistemarekin, non $A=\left(\begin{array}{cc}a-\mu U & b \\ c & d-v U\end{array}\right)$ baita,

$s^{\prime} \in\{0, \ldots, N-1\}$ izanik. (14) sistema ebazteko, bi ekuazio independenteen soluzioen itxuraz baliatuko gara ${ }^{24}$. Argi dago (14) sistemaren soluzioetako bat nulua dela, baina informaziorik ematen ez duenez, gainerakoak bilatuko ditugu. Horretarako, $A$ matrizearen polinomio karakteristikoa eta berorren erroak lortu behar ditugu. Alde batetik,

$$
\begin{aligned}
\chi(\lambda) & =\operatorname{det}\left(A-I_{2} \lambda\right)=\left|\begin{array}{cc}
a-\mu U-\lambda & b \\
c & d-v U-\lambda
\end{array}\right| \\
& =(a-\mu U-\lambda)(d-v U-\lambda)-b c=0 \\
& \Leftrightarrow \lambda^{2}-\lambda(a-\mu U-d-v U)+(a-\mu U)(d-v U)-b c=0 .
\end{aligned}
$$

Bestetik,

$$
\begin{aligned}
\lambda_{j}= & \frac{(a-\mu U)+(d-v U)}{2} \\
& +(-1)^{j} \frac{\sqrt{[(a-\mu U)+(d-v U)]^{2}-4[(a-\mu U)(d-v U)-b c]}}{2} \\
= & \frac{a+d}{2}-\frac{(\mu+v) U}{2}+(-1)^{j} \frac{\sqrt{4\left(\frac{a-\mu U}{2}-\frac{d-v U}{2}\right)^{2}+4 b c}}{2} \\
= & \frac{a+d}{2}-\frac{(\mu+v) U}{2}+(-1)^{j} \sqrt{\left(\frac{a-d}{2}+\frac{(v-\mu) U}{2}\right)^{2}+b c,}
\end{aligned}
$$

non $j \in\{1,2\}$ baita. Lortu ditugun balio propioak bazterreko erreakzio-tasen, difusio-koefizienteen eta $U$-ren menpekoak dira. Balio propioen diskriminantearen arabera, balio propioen inguruko informazio hau atera dezakegu:

${ }^{24}$ Irakurleak, behar izanez gero, [22, 4. kapitulua] liburuan azaltzen den teoria begiratu dezake ekuazio-sistema mota hauen soluzioen bilaketa-prozesua gogoratzeko. 
$-\left(\frac{a-d}{2}+\frac{(v-\mu) U}{2}\right)^{2}+b c>0 \quad$ bada, $\lambda_{1}, \lambda_{2} \in \mathbb{R}, \lambda_{1} \neq \lambda_{2}$ izanik.

$-\left(\frac{a-d}{2}+\frac{(v-\mu) U}{2}\right)^{2}+b c=0 \quad$ bada, $\lambda_{1}, \lambda_{2} \in \mathbb{R}, \lambda_{1}=\lambda_{2}$ izanik (balio propio bikotza).

$-\left(\frac{a-d}{2}+\frac{(v-\mu) U}{2}\right)^{2}+b c<0 \quad$ bada, $\lambda_{1}, \lambda_{2} \in \mathbb{C}, \lambda_{2}=\bar{\lambda}_{1}$ izanik.

Orduan, (13)-ren soluzioak honela sailka ditzakegu balio propioen arabera, $v_{j} \lambda_{j}$ balio propioari elkartutako bektore propioa izanik, non $j \in\{1,2\}$ baita:

$-\lambda_{1}, \lambda_{2} \in \mathbb{R}$ direnean, $\lambda_{1} \neq \lambda_{2}$ izanik:

$\left(\begin{array}{l}\xi_{s^{\prime}} \\ \eta_{s^{\prime}}\end{array}\right)=\left(\begin{array}{l}k_{11} \\ k_{21}\end{array}\right) e^{\lambda_{1} t}+\left(\begin{array}{l}k_{12} \\ k_{22}\end{array}\right) e^{\lambda_{2} t}$, non $k_{j q} \in \mathbb{C}$ baitira $\forall j, q \in\{1,2\}$.

$-\lambda_{1}, \lambda_{2} \in \mathbb{R}$ direnean, $\lambda_{1}=\lambda_{2}$ eta $v_{1}$ eta $v_{2}$ linealki mendekoak izanik:

$$
\left(\begin{array}{c}
\xi_{s^{\prime}} \\
\eta_{s^{\prime}}
\end{array}\right)=\left[\left(\begin{array}{c}
\hat{k}_{11} \\
\hat{k}_{21}
\end{array}\right)+\left(\begin{array}{c}
\hat{k}_{12} \\
\hat{k}_{22}
\end{array}\right) t e^{\lambda_{1} t}, \text { non } \hat{k}_{j q} \in \mathbb{C} \text { baitira } \forall j, q \in\{1,2\} .\right.
$$

$-\lambda_{1}, \lambda_{2} \in \mathbb{R}$ direnean, $\lambda_{1}=\lambda_{2}$ eta $v_{1}$ eta $v_{2}$ linealki askeak izanik:

$$
\left(\begin{array}{c}
\xi_{s^{\prime}} \\
\eta_{s^{\prime}}
\end{array}\right)=\left(\begin{array}{c}
\breve{k}_{11} \\
\breve{k}_{21}
\end{array}\right) e^{\lambda_{1} t} \text {, non } \breve{k}_{j 1} \in \mathbb{C} \text { baitira } \forall j \in\{1,2\} \text {. }
$$

$-\lambda_{1}, \lambda_{2} \in \mathbb{C}$ direnean, $\lambda_{2}=\bar{\lambda}_{1}$ izanik:

$$
\begin{aligned}
& \left(\begin{array}{c}
\xi_{s^{\prime}} \\
\eta_{s^{\prime}}
\end{array}\right)=e^{\alpha t}\left(\begin{array}{c}
\tilde{k}_{11} \cos \beta t+\tilde{k}_{12} \sin \beta t \\
\tilde{k}_{21} \cos \beta t+\tilde{k}_{22} \sin \beta t
\end{array}\right), \\
& \text { non } \lambda_{1}=\alpha+i \beta \in \mathbb{C} \text { eta } \tilde{k}_{j q} \in \mathbb{C} \text { baitira } \forall j, q \in\{1,2\} .
\end{aligned}
$$


8. oharra. Ohar honetan, eman berri dugun balio propioen araberako sailkapenaren inguruko ideia batzuk txertatuko ditugu.

(i) Eulerren berdintzari esker, sailkapen horretako lehenengo eta laugarren kasuak bateratu daitezke, laugarren kasuko soluzioak honela adieraz baitaitezke:

$$
\begin{aligned}
\left(\begin{array}{c}
\xi_{s^{\prime}} \\
\eta_{s^{\prime}}
\end{array}\right) & =\left(\begin{array}{l}
\frac{\tilde{k}_{11}-i \tilde{k}_{12}}{2} e^{\lambda_{1} t}+\frac{\tilde{k}_{11}-i \tilde{k}_{12}}{2} e^{\lambda_{2} t} \\
\frac{\tilde{k}_{21}-i \tilde{k}_{22}}{2} e^{\lambda_{1} t}+\frac{\tilde{k}_{21}-i \tilde{k}_{22}}{2} e^{\lambda_{2} t}
\end{array}\right) \\
& =\left(\begin{array}{l}
\frac{\tilde{k}_{11}-i \tilde{k}_{12}}{2} \\
\frac{\tilde{k}_{21}-i \tilde{k}_{22}}{2}
\end{array}\right) e^{\lambda_{1} t}+\left(\begin{array}{c}
\frac{\tilde{k}_{11}-i \tilde{k}_{12}}{2} \\
\frac{\tilde{k}_{21}-i \tilde{k}_{22}}{2}
\end{array}\right) e^{\lambda_{2} t},
\end{aligned}
$$

non $\lambda_{2}=\bar{\lambda}_{1}$ eta $\tilde{k}_{j q} \in \mathbb{C}$ baitira $\forall j, q \in\{1,2\}$.

(ii) Sailkapeneko hirugarren kasuari dagokionez, kimikoki interesgarria ez dela esan dezakegu (Turingek [19] artikuluan ez zuen aintzat hartu ere egin). Izan ere, substantziek euren artean interakziorik ez dutela ondorioztatzen da, jarraian arrazoituko dugun gisan. Dakigunez, egoera horretan azpiespazio propioaren dimentsioa bi da, bi bektore linealki aske dituelako: $v_{1}$ eta $v_{2}$. Orduan, adierazpen ezagun hau erabiliz,

$$
\operatorname{rg}\left(A-I_{2} \lambda_{1}\right)=m-\operatorname{dim}\left(V\left(\lambda_{1}\right)\right),
$$

non $m A-I_{2} \lambda_{1}$ matrize karratuaren dimentsioa eta $V\left(\lambda_{1}\right)$ ren oinarri bat $\left\{v_{1}, v_{2}\right\}$ baitira, $\operatorname{rg}\left(A-I_{2} \lambda_{1}\right)=0$ lortuko dugu; hots, $A-I_{2} \lambda_{1}$ matrize nulua izango da. Ondorioz, $A=I_{2} \lambda_{1}$ izanik, (14) adierazpeneko $A$ matrizeari erreparatuz, $b=c=0$ eta $a-\mu U=d-v U=\lambda_{1}$ berdintzak lortuko ditugu.

(iii) Aipatu ditugun sailkapeneko kasu interesgarrien (lehenengo, bigarren eta laugarren kasuen) soluzioak bateratzeko aukera izango dugu. Soluzio bateratu horrek itxura hau izango du:

$$
\left(\begin{array}{c}
\xi_{s^{\prime}} \\
\eta_{s^{\prime}}
\end{array}\right)=\left(\begin{array}{c}
A_{s^{\prime}}+\widetilde{A_{s^{\prime}} t} \\
C_{s^{\prime}}+\widetilde{C_{s^{\prime}} t}
\end{array}\right) e^{\lambda_{1} t}+\left(\begin{array}{c}
B_{s^{\prime}} \\
D_{s^{\prime}}
\end{array}\right) e^{\lambda_{2} t}, \quad A_{s^{\prime}}, \widetilde{A_{s^{\prime}}}, B_{s^{\prime}}, C_{s^{\prime}}, \widetilde{C_{s^{\prime}}}, D_{s^{\prime}} \in \mathbb{C} \text { izanik. }
$$


Behin (13) sistemari dagozkion soluzioak lortuta, azter ditzagun konstante arbitrarioek kasu bakoitzean bete behar dituzten baldintzak ${ }^{25}$. Baldintza horiek zehazteko, lortu berri ditugun $\xi_{s^{\prime}}(t)$ eta $\eta_{s^{\prime}}(t)$ koordenatu laguntzaileen adierazpenak (13) sisteman ordezkatu behar ditugu.

\subsection{Soluzioetako koefizienteek bete behar dituzten baldintzak}

Azpiatal honetan, eman berri ditugun soluzioetako konstanteek euren artean bete behar dituzten erlazioak txertatuko ditugu. Garapen esplizituak alde batera utziko ditugun arren, lehenengo autobalioen kasurako (autobalio errealak eta ezberdinak) laburki azalduko dugu zein pauso eman behar diren erlazio horiek lortzeko. Gainontzeko kasuetan, prozesu bera jarraituta lortzen dira koefizienteen arteko baldintzak.

Funtsezkoa da koefizienteek euren artean bete behar dituzten erlazioak ezagutzea; izan ere, erlazio horiek bete ezean, ez dugu sistemaren soluziorik lortuko. Dena dela, soluzioak guztiz zehaztu nahiko bagenitu, ebazten ari garen problemaren hastapen- eta muga-baldintzak finkatu beharko genituzke.

$-\lambda_{1}, \lambda_{2} \in \mathbb{R}$ eta $\lambda_{1} \neq \lambda_{2}$ direnean, (13) sistemaren soluzioaren konstanteek bete behar dituzten baldintzak honako hauek dira, $s^{\prime} \in\{0, \ldots$, $N-1$ \} izanik:

$$
\left\{\begin{array}{l}
\left(\lambda_{1}-a+4 \mu \sin ^{2}\left(\frac{\pi s^{\prime}}{N}\right)\right) k_{11}=b k_{21} \\
\left(\lambda_{2}-a+4 \mu \sin ^{2}\left(\frac{\pi s^{\prime}}{N}\right)\right) k_{12}=b k_{22}
\end{array}\right.
$$

Berdintza horietara heltzeko, $\xi_{s^{\prime}}$ eta $\eta_{s^{\prime}}$ funtzioen adierazpenak (13) sisteman ordezkatu behar dira. Lortzen diren berdintzen bi aldeetan, $e^{\lambda_{1} t}$ eta $e^{\lambda_{2} t}$ funtzioen koefizienteak berdinduta, lau ekuazio aterako dira, $k_{11}, k_{12}, k_{21}$ eta $k_{22}$ koefizienteak erlazionatzen dituztenak, hain zuzen ere. Horietako bi ekuazio, goian txertatu ditugunak, lauretatik elkarren artean independenteak diren bakarrak dira, $\lambda_{1}$ eta $\lambda_{2}(15)$ polinomio karakteristikoaren soluzioak direlako.

$-\lambda_{1}=\lambda_{2} \in \mathbb{R}$ eta $v_{1}$ eta $v_{2}$ linealki mendekoak direnean, (13) sistemaren soluzioaren konstanteek bete behar dituzten baldintzak honako hauek dira, $s^{\prime} \in\{0, \ldots, N-1\}$ izanik:

\footnotetext{
25 Turingek (13) sistemaren soluzioetako koefizienteek euren artean bete behar zituzten baldintzak txertatu zituen $[19,48$. or.]-n.
} 


$$
\left\{\begin{array}{l}
\hat{k}_{12}+\left(\lambda_{1}-a+4 \mu \sin ^{2}\left(\frac{\pi s^{\prime}}{N}\right)\right) \hat{k}_{11}=b \hat{k}_{21} \\
\left(\lambda_{2}-a+4 \mu \sin ^{2}\left(\frac{\pi s^{\prime}}{N}\right)\right) \hat{k}_{12}=b \hat{k}_{22}
\end{array} .\right.
$$

$-\lambda_{1}=\lambda_{2} \in \mathbb{R}$ eta $v_{1}$ eta $v_{2}$ linealki askeak direnean, (13) sistemaren soluzioaren konstanteetarako ez daukagu baldintzarik. Izan ere, (13)-ren soluzioen sailkapenean ikusi dugun bezalaxe, bete behar dituzten baldintzak honako hauek dira, $s^{\prime} \in\{0, \ldots, N-1\}$ izanik:

$$
\left\{\begin{array}{c}
\left(\lambda_{1}-a+4 \mu \sin ^{2}\left(\frac{\pi s^{\prime}}{N}\right)\right) \breve{k}_{11}=b \breve{k}_{21} \\
\left(\lambda_{2}-d+4 v \sin ^{2}\left(\frac{\pi s^{\prime}}{N}\right)\right) \breve{k}_{21}=c \breve{k}_{11}
\end{array} .\right.
$$

Hala ere, 8. oharreko (ii) atalagatik, $b=c=0$ eta $a-\mu U=d-\nu U=\lambda_{1}$ betetzen direnez, goiko bi ekuazioetan $0=0$ lortuko dugu.

$-\lambda_{1}, \lambda_{2} \in \mathbb{C}$ eta $\lambda_{2}=\bar{\lambda}_{1}=\overline{\alpha+i \beta}$ betetzen denean, (13) sistemaren soluzioaren konstanteek bete behar dituzten baldintzak hauek dira, $s^{\prime} \in\{0, \ldots, N-1\}$ izanik:

$$
\left\{\begin{array}{l}
\left(\lambda_{1}-a+4 \mu \sin ^{2}\left(\frac{\pi s^{\prime}}{N}\right)\right)\left(\tilde{k}_{11}-i \tilde{k}_{12}\right)=b\left(\tilde{k}_{21}-i \tilde{k}_{22}\right) \\
\left(\lambda_{2}-a+4 \mu \sin ^{2}\left(\frac{\pi s^{\prime}}{N}\right)\right)\left(\tilde{k}_{11}+i \tilde{k}_{12}\right)=b\left(\tilde{k}_{21}+i \tilde{k}_{22}\right)
\end{array} .\right.
$$

Erlazio horiek lortzeko, pauso hauek eman behar dira:

(i) Hasteko, $\xi_{s^{\prime}}$ eta $\eta_{s^{\prime}}$ funtzioen adierazpenak (13) sisteman ordezkatu eta $e^{a t}$ funtzioarekin sinplifikatzen dira ekuazioaren bi aldeak:

$$
\left\{\begin{array}{l}
\alpha\left(\tilde{k}_{11} \cos \beta t+\tilde{k}_{12} \sin \beta t\right)-\beta \tilde{k}_{11} \sin \beta t+\beta \tilde{k}_{12} \cos \beta t \\
=(a-\mu U)\left(\tilde{k}_{11} \cos \beta t+\tilde{k}_{12} \sin \beta t\right)+b\left(\tilde{k}_{21} \cos \beta t+\tilde{k}_{22} \sin \beta t\right) \\
\alpha\left(\tilde{k}_{21} \cos \beta t+\tilde{k}_{22} \sin \beta t\right)-\beta \tilde{k}_{21} \sin \beta t+\beta \tilde{k}_{22} \cos \beta t \\
=c\left(\tilde{k}_{11} \cos \beta t+\tilde{k}_{12} \sin \beta t\right)+(d-v U)\left(\tilde{k}_{21} \cos \beta t+\tilde{k}_{22} \sin \beta t\right)
\end{array}\right.
$$


(ii) Aurreko pausoko ekuazio bakoitza, lehenengo, $\sin \beta t$ funtzioarekin biderkatu eta $\left[-\frac{\pi}{\beta}, \frac{\pi}{\beta}\right]$ tartean integratzen da, eta, bigarrenik, $\cos \beta t$ funtzioarekin biderkatu eta tarte berean integratu behar da. Horretarako, $\{1, \sin \beta t, \cos \beta t\}$ sistema $\left[-\frac{\pi}{\beta}, \frac{\pi}{\beta}\right]$ tartean $\langle f, g\rangle=\int_{-\frac{\pi}{\beta}}^{\frac{\pi}{\beta}} f(t) \cdot g(t) d t$ biderkadura eskalarrarekiko ortogonala dela erabiltzen da. Hauek dira geratzen diren lau ekuazioak:

$$
\left\{\begin{array}{c}
\alpha \tilde{k}_{12}-\beta \tilde{k}_{11}=(a-\mu U) \tilde{k}_{12}+b \tilde{k}_{22} \\
\alpha \tilde{k}_{11}+\beta \tilde{k}_{12}=(a-\mu U) \tilde{k}_{11}+b \tilde{k}_{21} \\
\alpha \tilde{k}_{22}-\beta \tilde{k}_{21}=c \tilde{k}_{12}+(d-v U) \tilde{k}_{22} \\
\alpha \tilde{k}_{21}+\beta \tilde{k}_{22}=c \tilde{k}_{11}+(d-v U) \tilde{k}_{21}
\end{array}\right.
$$

(iii) Alde batetik, aurreko urratseko ekuazioen artean (19)-i(18) eragiketa eginez, (16)-ko lehenengo berdintza lortzen da. Bestetik, (19) $+i(18)$ eragiketa eginez gero, (16)-ko bigarren berdintzara iritsiko gara.

(iv) Era antzekoan, (ii) pausoko ekuazioen arteko (21)-i(20) eta $(21)+i(20)$ eragiketak eginez eta (15) polinomio karakteristikoa erabiliz, ikus daiteke lortzen diren bi ekuazioak (iii) pausoan lortutakoak direla. Hortaz, $\tilde{k}_{11}, \tilde{k}_{12}, \tilde{k}_{21}$ eta $\tilde{k}_{22}$ koefizienteen arteko erlazioak (16)-ko bi ekuazioekin guztiz zehaztuta geratuko dira.

9. oharra. Laugarren kasuko baldintzak lortzeko beste era bat azalduko dugu hemen. Modu hori 8. oharreko (i) ataletik lor ditzakegun lehen kasuko soluzioetako $k_{j q}$ koefizienteen eta laugarren kasuko soluzioetako $\tilde{k}_{j q}$ koefizienteen arteko erlazioez baliatzean datza; hots, erlazio hauetan oinarritzea:

$$
\left(\begin{array}{l}
k_{11} \\
k_{21}
\end{array}\right)=\left(\begin{array}{c}
\frac{\tilde{k}_{11}-i \tilde{k}_{12}}{2} \\
\frac{\tilde{k}_{21}-i \tilde{k}_{22}}{2}
\end{array}\right) \text { eta }\left(\begin{array}{c}
k_{12} \\
k_{22}
\end{array}\right)=\left(\begin{array}{c}
\frac{\tilde{k}_{11}+i \tilde{k}_{12}}{2} \\
\frac{\tilde{k}_{21}+i \tilde{k}_{22}}{2}
\end{array}\right)
$$

Laugarren kasuko baldintzetara heltzeko, lehenengo kasuko koefizienteek bete behar dituzten baldintzetan koefizienteen arteko (22) erlazioak ordezkatu behar ditugu. 


\section{3. (6) sistemaren soluzioa}

Analisi guztiaren ostean, 8. oharreko (iii) atala kontuan izango dugu, eta egindako aldagai-aldaketak desegingo ditugu. Behin hori eginda, (6) sistema diskretuko kontzentrazioetarako honako soluzio hauek lortuko ditugu. Soluzioak bazterreko erreakzio-tasen $(a, b, c$ eta $d)$ zein difusio-koefizienteen $(\mu$ eta $v)$ menpeko emaitzak izango dira, $\forall(r, t) \in\{1, \ldots, N\} \times(0, \infty)$,

$$
\left\{\begin{array}{c}
X_{r}=h+\sum_{s^{\prime}=0}^{N-1} \exp \left(\frac{2 \pi i r s^{\prime}}{N}\right)\left[\left(A_{s^{\prime}}+\tilde{A}_{s^{\prime}}\right) e^{\lambda_{1} t}+B_{s^{\prime}} e^{\lambda_{2} t}\right] \\
Y_{r}=k+\sum_{s^{\prime}=0}^{N-1} \exp \left(\frac{2 \pi i r s^{\prime}}{N}\right)\left[\left(C_{s^{\prime}}+\tilde{C}_{s^{\prime}} t\right) e^{\lambda_{1} t}+D_{s^{\prime}} e^{\lambda_{2} t}\right]
\end{array},\right.
$$

non $A_{s^{\prime}}, \tilde{A}_{s^{\prime}}, B_{s^{\prime}}, C_{s^{\prime}}, \tilde{C}_{s^{\prime}}, D_{s^{\prime}} \in \mathbb{C}$ baitira.

\section{0. oharra.}

(i) Kontuan hartu behar dugu soluzioaren koefizienteak hainbat modutan lortuko ditugula $s^{\prime}$-ren arabera; hots, balio propioen izaeraren arabera.

(ii) Teorikoki edozein kontzentrazio lor daitekeen arren, deskribatu nahi dugun egoerarekin bat egiteko, morfogeneen kontzentrazioak erreal ez -negatiboak izan behar dira, horiek baitira kimikoki posibleak direnak.

(iii) Turingen artikuluko $[19,(6.11)]$ soluzioari erreparatzen badiogu, balio propio berdinen eta bektore propio linealki mendekoen kasua alde batera utzi zuela ikus daiteke. Hori egitearen arrazoia hau dela uste dugu: oro har, Turingen patroiak agertzeko, difusio-koefizienteak ezberdinak direla onartzen da, eta, balio propioak horien menpekoak direnez, gutxitan gertatuko da balio propioak berdinak izatea. Ondorioz, uste dugu Turingek, bere ondorengo ikerketan eragiketak sinplifikatzearren, balio propio ezberdinen kasuko soluzioa soilik hartu zuela kontuan.

\section{ERAZTUN JARRAITUKO GARAPEN MATEMATIKOA}

Alan Turingek aztertu zuen bigarren eredua zelulaz osatutako ehun jarraitua izan zen, [19, 7. atala], «Continuous Ring of Tissue» izenburupean, simetria zilindrikoa duen espazioa. Eremu honetan, zelula kopurua infinitua izango da, eta zelulek ez dute modu isolatuan funtzionatuko; hots, ez dira zelula banandutzat hartuko. Demagun aipatu berri dugun eraztuna hau dela:

$$
E=\left\{\rho e^{i \theta}: \rho \in\left(\rho_{1}, \rho_{2}\right), \theta \in[0,2 \pi]\right\}, \rho_{1}, \rho_{2} \in \mathbb{R}^{+} \text {eta } \rho_{1}<\rho_{2} \text { izanik. }
$$


$E$ eraztuneko puntuak identifikatzeko, aztertu nahi dugun puntuaren eta jatorriaren arteko zuzenkiaren luzera, $\rho$, eta $\rho$ erradioak $O X$ ardatz positiboarekiko osatzen duen angelua, $\theta$, zehaztu behar ditugu (ikus 2 . irudia). Demagun zelulen arteko difusio-koefizienteak $\mu^{\prime}$ eta $v^{\prime}$ direla, 3. atalean erabili ditugun difusio-koefizienteen ezberdinak. Izan ere, 3 . atalean erabili ditugunak zelula-diametroa zeukaten luzera-unitate gisa, eta oraingoan, aldiz, neurketa-unitatea $\rho$ erradioak duena izango da (ikus $[19,49$. or.]). Hala ere, difusio-koefizienteen artean, honako erlazio hau defini dezakegu:

$$
\mu=\mu^{\prime}\left(\frac{N}{2 \pi \rho}\right)^{2} \quad \text { eta } \quad v=v^{\prime}\left(\frac{N}{2 \pi \rho}\right)^{2} .
$$

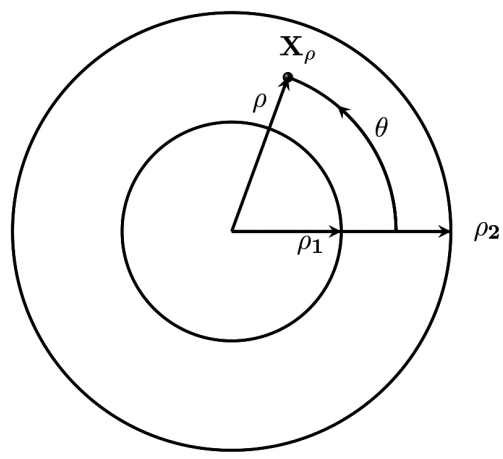

2. irudia. $\rho_{1}$ eta $\rho_{2}$ erradioen arteko eraztun jarraitua.

Demagun $E$ eraztunean aztertuko ditugun bi substantzia kimikoak $X$ eta $Y$ morfogeneak direla. Horiei lotuta, $X_{\rho}=X(\rho, \theta, t)$ eta $Y_{\rho}=Y(\rho, \theta, t)$ funtzioek $t$ uneko $\rho$ erradio finkoa eta $\theta$ angelua dituen puntuko $X$ eta $Y$ substantzien kontzentrazioak adieraziko dituzte, hurrenez hurren, $\forall(\rho, \theta, t) \in\left(\rho_{1}, \rho_{2}\right) \times[0,2 \pi] \times(0, \infty)$.

Funtzio horietan oinarrituta, Turingek zelulaz osatutako eraztun jarraituaren eremurako erreakzio-difusio sistema hau planteatu zuen:

$$
\left\{\begin{array}{c}
\frac{\partial X_{\rho}}{\partial t}=f\left(X_{\rho}, Y_{\rho}\right)+\frac{\mu^{\prime} \partial^{2} X_{\rho}}{\rho^{2} \partial \theta^{2}} \\
\frac{\partial Y_{\rho}}{\partial t}=g\left(X_{\rho}, Y_{\rho}\right)+\frac{v^{\prime} \partial^{2} Y_{\rho}}{\rho^{2} \partial \theta^{2}}
\end{array},\right.
$$

non $\rho \in\left(\rho_{1}, \rho_{2}\right)$ eta $f\left(X_{\rho}, Y_{\rho}\right)$ zein $g\left(X_{\rho}, Y_{\rho}\right)$ morfogeneen arteko erreakzioaren adierazpide baitira; hots, erreakzio zinetikoak. Bigarren ordenako deribatuen terminoak difusioaren adierazle dira. 
11. oharra. Turingek eraztun jarraiturako (23) erreakzio-difusio sistema planteatu zuenean, $X_{\rho}$ funtzioaren laplacetarrak koordenatu polarretan duen

$$
\Delta X_{\rho}=\frac{1}{\rho} \frac{\partial}{\partial \rho}\left(\rho \frac{\partial X_{\rho}}{\partial \rho}\right)+\frac{1}{\rho^{2}} \frac{\partial^{2} X_{\rho}}{\partial \theta^{2}}
$$

adierazpen orokorra erabili beharrean, difusio terminoetarako, $\frac{\partial^{2} X_{\rho}}{\rho^{2} \partial \theta^{2}}$ eta $\frac{\partial^{2} Y_{\rho}}{\rho^{2} \partial \theta^{2}}$ gaiak erabili zituen soilik. Horren arrazoia da laplacetarraren $\rho$ aldagaiarekiko deribatuaren terminoa zero dela $\rho$ erradioa finkatzen dugulako sistema bakoitzerako.

Lehenengo eta behin, 2.3. atalean azaldu dugun linealizazio-prozesua erabiliko dugu (23) sistema koefiziente konstantedun ekuazio diferentzial linealen sistema bihurtzeko. Demagun sistemak oreka-puntu bat duela $(h, k)$ puntuan $\rho \in\left(\rho_{1}, \rho_{2}\right)$ izanik ${ }^{26}$, non $X$ eta $Y$ substantzien kontzentrazioen banaketak guztiz uniformeak baitira. Orduan, $f$ zein $g$ funtzioak $(h, k)$ oreka-puntutik hurbil dagoen puntu batean ebaluatuta (esate baterako, $\left(x_{\rho}+h, y_{\rho}+k\right)$ puntuan), funtzio linealen bidez hurbil ditzakegu (ikus 2.3. azpiatala):

$$
\left\{\begin{array}{l}
f\left(X_{\rho}, Y_{\rho}\right)=f\left(h+x_{\rho}, k+y_{\rho}\right)=a x_{\rho}+b y_{\rho} \\
g\left(X_{\rho}, Y_{\rho}\right)=g\left(h+x_{\rho}, k+y_{\rho}\right)=c x_{\rho}+d y_{\rho}
\end{array},\right.
$$

non $\rho \in\left(\rho_{1}, \rho_{2}\right)$ eta $a, b, c$ zein $d$ bazterreko erreakzio-tasak baitira (ikus 2. definizioa). Suposatuko dugu $x_{\rho}$ eta $y_{\rho}$ perturbazioak jarraituak direla eta mutur kopuru finitua dutela $[0,2 \pi]$ tartean, ostera beharko ditugun baldintzak baitira. Horrez gain, demagun gora-behera horiek $t$ zein $\theta$ aldagaiekiko ausazkoak direla.

Oreka-puntuko koordenatuak perturbatzetik lortu dugun informazioa kontuan hartuta, (23) sistema honela berridatz dezakegu $x_{\rho}$-ren eta $y_{\rho}$-ren menpe,

$$
\left\{\begin{array}{c}
\frac{\partial x_{\rho}}{\partial t}=a x_{\rho}+b y_{\rho}+\frac{\mu^{\prime} \partial^{2} x_{\rho}}{\rho^{2} \partial \theta^{2}} \\
\frac{\partial y_{\rho}}{\partial t}=c x_{\rho}+d y_{\rho}+\frac{v^{\prime} \partial^{2} y_{\rho}}{\rho^{2} \partial \theta^{2}}
\end{array}\right.
$$

non $\rho \in\left(\rho_{1}, \rho_{2}\right)$ eta $a, b, c$ zein $d$ bazterreko erreakzio-tasak baitira.

${ }^{26}$ Gogoratu 2.3. atalean azaldu duguna: Turingek oreka-puntu egonkorrak difusiorik gabeko sisteman aztertu zituen, difusioa gehitzean ezegonkor bihurtuko zirenak. 
Kontuan izanda $x_{\rho}$ eta $y_{\rho}$ funtzioak jarraituak eta $2 \pi$ periododunak direla $\theta$ aldagaiarekiko, Fourierren serie gisa adieraz ditzakegu aldagai horrekiko. Gainera, $x_{\rho}$ eta $y_{\rho}$ funtzioek $[0,2 \pi]$ tartean mutur kopuru finitua dutela suposatu dugunez, 1. teorema erabiliz, Fourierren seriezko garapenak $x_{\rho}$ eta $y_{\rho}$ funtzioetara konbergenteak direla ziurta dezakegu. Hau da,

$$
x_{\rho}(\theta, t)=\sum_{s=-\infty}^{\infty} e^{i \theta s} G_{s}(t) \quad \text { eta } \quad y_{\rho}(\theta, t)=\sum_{s=-\infty}^{\infty} e^{i \theta s} H_{s}(t)
$$

har ditzakegu, non $\theta \in[0,2 \pi]$ eta $t \in(0, \infty)$ baitira, $\rho \in\left(\rho_{1}, \rho_{2}\right)$ izanik. Aurrerago egingo dugun garapenean deribagarritasuna eta serieak erlazionatzen dituen kalkuluko teorema bat aplikatu ahal izateko, jarraian txertatuko ditugun serieak $E$ eraztunean uniformeki konbergenteak direla suposatuko dugu:

$$
\begin{gathered}
\sum_{s=-\infty}^{\infty} e^{i \theta s} G_{s}^{\prime}(t), \sum_{s=-\infty}^{\infty} e^{i \theta s} H_{s}^{\prime}(t), \sum_{s=-\infty}^{\infty} i s e^{i \theta s} G_{s}(t) \\
\sum_{s=-\infty}^{\infty}\left(-s^{2}\right) e^{i \theta s} G_{s}(t), \sum_{s=-\infty}^{\infty} i s e^{i \theta s} H_{s}(t) \text { eta } \sum_{s=-\infty}^{\infty}\left(-s^{2}\right) e^{i \theta s} H_{s}(t) .
\end{gathered}
$$

Ordezka ditzagun (25) adierazpenak (24) sistemaren lehenengo ekuazioan eta erabil dezagun kalkuluko funtzio-serieen teoriako deribagarritasuna eta funtzio-serieen konbergentzia uniformea erlazionatzen duen teorema (ikus $\left[3,5\right.$. kapitulua]). Ondorioz, $\rho \in\left(\rho_{1}, \rho_{2}\right)$ izanik,

$$
\begin{gathered}
\frac{d}{d t} \sum_{s=-\infty}^{\infty} e^{i \theta s} G_{s}=a \sum_{s=-\infty}^{\infty} e^{i \theta s} G_{s}+b \sum_{s=-\infty}^{\infty} e^{i \theta s} H_{s}+\frac{\mu^{\prime}}{\rho^{2}} \frac{\partial^{2}}{\partial \theta^{2}}\left(\sum_{s=-\infty}^{\infty} e^{i \theta s} G_{s}\right) \\
\Leftrightarrow \sum_{s=-\infty}^{\infty} e^{i \theta s} \frac{d G_{s}}{d t}=\sum_{s=-\infty}^{\infty} e^{i \theta s}\left[\left(a-\frac{\mu^{\prime}}{\rho^{2}} s^{2}\right) G_{s}+b H_{s}\right] .
\end{gathered}
$$

Orduan, 5. oharrean oinarrituz, $e^{i \theta s}$ funtzioak linealki askeak direnez $\forall s \in \mathbb{Z}$, hau betetzen da:

$$
\frac{d G_{s}}{d t}=\left(a-\frac{\mu^{\prime}}{\rho^{2}} s^{2}\right) G_{s}+b H_{s} .
$$

(24) sistemaren bigarren ekuazioari lehenengoari egin diogun prozesu bera aplikatzen badiogu, (24) sistema honela berridatz dezakegu: 


$$
\left\{\begin{array}{l}
\frac{d G_{s}}{d t}=\left(a-\frac{\mu^{\prime}}{\rho^{2}} s^{2}\right) G_{s}+b H_{s} \\
\frac{d H_{s}}{d t}=c G_{s}+\left(d-\frac{v^{\prime}}{\rho^{2}} s^{2}\right) H_{s}
\end{array}, \forall s \in \mathbb{Z} .\right.
$$

Sistema hori Turingen sistema gisa ezagutzen da. Koefiziente konstantedun ekuazio diferentzial linealen sistema denez, soluzioa lortzeko, polinomio karakteristikoa erabiliko dugu, 3. atalean egin dugun bezalaxe. Hauek dira (26) sistemari dagozkion balio propioak:

$\lambda_{j}=\frac{a+d}{2}-\frac{\left(\mu^{\prime}+v^{\prime}\right)}{2 \rho^{2}} s^{2}+(-1)^{j} \sqrt{\left(\frac{a-d}{2}-\frac{\left(\mu^{\prime}+v^{\prime}\right)}{2 \rho^{2}} s^{2}\right)^{2}+b c}$, non $j \in\{1,2\}$ baita.

3. ataleko arrazoiketa bera erabiliz, $s$-ren balio bakoitzerako (eta, beraz, balio propio bakoitzerako) $G_{s}$-ren eta $H_{s}$-ren adierazpenak lortuta eta (25) serieetan ordezkatuta, (23) sistemaren soluzio orokor hau lortuko dugu: $\forall(\rho, \theta, t) \in\left(\rho_{1}, \rho_{2}\right) \times[0,2 \pi] \times(0, \infty)$,

$$
\left\{\begin{array}{c}
X_{\rho}=h+\sum_{s=-\infty}^{\infty} e^{i \theta s}\left[\left(A_{s}+\tilde{A}_{s} t\right) e^{\lambda_{1} t}+B_{s} e^{\lambda_{2} t}\right] \\
Y_{\rho}=k+\sum_{s=-\infty}^{\infty} e^{i \theta s}\left[\left(C_{s}+\tilde{C}_{s} t\right) e^{\lambda_{1} t}+D_{s} e^{\lambda_{2} t}\right]
\end{array},\right.
$$

non $A_{s}, \tilde{A}_{s}, B_{s}, C_{s}, \tilde{C}_{s}, D_{s} \in \mathbb{C}$ baitira.

12. oharra. $[19,(7.2)]$ sisteman ikus daiteke Turing balio propio ezberdinen kasuak ematen duen soluzioaren adierazpenarekin soilik geratu zela. Hori egitearen arrazoia 3. ataleko 10. oharreko (iii) atalean aipatu duguna dela uste dugu.

\section{TURINGEN [19] ARTIKULUKO BESTE IDEIA BATZUK ETA ANALISI MATEMATIKOAREN APLIKAZIO BIOLOGIKOA}

Atal honetan, Turingek [19] artikuluan landu zituen beste atal batzuetako ideiak bilduko ditugu. Horrez gain, lortutako soluzioek animalien ilajeetan dauden patroiekin duten erlazioa ikusteko, emaitza matematikoetatik ondorio ikusgarriak lortzeko bidea zein izan daitekeen azalduko dugu. 
Morfogenesiaren mekanismoa hobeto ulertzeko, Turingek esfera erabili zuen, konplexuagoa den eremua. «Chemical Waves on Spheres. Gastrulation» atalean, [19, 69-71 or.], erreakzio-difusio sistema bat planteatu zuen, eta, sistema hori ebazteko, Fourierren serieen analogoak diren harmoniko esferikoak erabili zituen.

Nahiz eta guk eraztun bakoitzari dagozkion substantzia arbitrarioen kontzentrazioei dagozkien soluzioak besterik ez ditugun lortu, Turingek soluzio horien joera asintotikoa ere aztertu zuen denboran zehar izango zuten bilakaerari erreparatzeko. [19] artikuluko «Types of Asymptotic Behaviour in the Ring After a Lapse of Time» eta «Further Consideration of the Mathematics of the Ring» ataletan landu zuen hori, zortzigarren eta bederatzigarren ataletan, hain zuzen ere. Era horretan, biologikoki adierazgarriak diren emaitzak lortzeko parada izan zuen.

Amaitzeko, lortu ditugun soluzioetatik biologikoki adierazgarria izango den informazioa lortzeko jarraitu daitezkeen bideak aipatuko ditugu. Alde batetik, Turingek lortutako soluzioen joera asintotikoaren azterketa egin daiteke soluzioek teorikoki zer nolako bilakaera izango duten ikusteko. Bestetik, ereduak zenbakizko metodoen bidez inplementa daitezke edota automata zelularrak erabil daitezke, soluzioak grafikoki adierazi eta ikusgarriak egin ahal izateko. Bide horretatik jarraituz, ereduetako parametroei balioak eman dakizkieke egongo diren aldaketak analizatu ahal izateko.

\section{ESKER ONAK}

Eskerrak eman nahi dizkiegu EKAIA aldizkariko begiraleei artikuluaren irakurketa sakona egiteagatik eta egindako ohar, zuzenketa eta gomendioengatik. Izan ere, artikulu hau zehatzagoa, argiagoa eta aberatsagoa izaten lagundu dutela uste dugu.

Matematikako kontzeptu eta arrazoibideekin laguntza eskaini diguten pertsonak eskertu nahi ditugu: Martín Blas Pérez Pinilla UPV/EHUko irakaslea, Fourierren serieen atalean egindako ohar eta gomendioengatik; Bartzelonako Unibertsitateko Jordi Soriano ikerlaria, Turingen artikuluko arrazoibideak beste ikuspuntu batetik ulertzen laguntzeagatik; eta Japoniako Ibaraki Unibertsitateko Kanako Suzuki ikerlaria, Turingen soluzioen inguruko interpretazioa helarazteagatik.

Euskarazko zuzenketa eta aholku linguistikoekin lagundu diguten Libe Arenaza, Julio García eta Andoni Landari eskerrak eman nahi dizkiegu proposatu dizkiguten ekarpen baliagarriengatik.

Jone Apraiz egileak Espainiako Gobernuaren Zientzia, Berrikuntza eta Unibertsitateen Ministerioaren (PGC2018-094522-B-I00) eta Eusko Jaurlaritzaren (IT12247-19) ikerketa-proiektuen laguntza jaso du. 


\section{BIBLIOGRAFIA}

[1] BEHRAVAN R., BENTLEY P. J. eta CARLISLE R. «Exploring ReactionDiffusion and Pattern Formation». Hemendik eskuratua: https://www.ee.ucl. ac.uk/lcs/ previous/LCS2003/83.pdf, azken bisita: 2020-10-04.

[2] BURDEN R. L. eta FAIRES D. 1998. Análisis Numérico, Sexta edición. International Thomson, México.

[3] BURGOS J. 2007. Cálculo infinitesimal de una variable, Segunda edición. McGraw-Hill / Interamericana de España S.A., Madrid.

[4] CHARÓ G. D. 2013. Simulación de patrones de Turing por elementos finitos. Departamento de Matemática, Facultad de Ciencias Exactas y Naturales, Universidad de Buenos Aires. Hemendik eskuratua: http://cms.dm.uba.ar/ academico/carreras/ licenciatura/tesis/2013/Gisela_Charo.pdf, azken bisita: 2020-10-04.

[5] COOPER S. B. eta VAN LEEUWEN J. 2013. Alan Turing: His Work and Impact, First Edition. Elsevier.

[6] DEUTSCH A. eta DORMANN S. 2017. Cellular Automaton Modeling of Biological Pattern Formation. Characterization, Examples, and Analysis, Second Edition. Modeling and Simulation in Science, Engineering \& Technology Series, Birkuser, Springer, New York.

[7] ELMER E. E. eta VAN VLECK E. S. 1996. «Computation of Traveling Waves for Spatially Discrete Bistable Reaction-Diffusion Equations». Applied Numerical Mathematics, 20, 157-169.

[8] GREENSIDE H. 2018. Fourier analysis of a $1 D$ diffusion equation. Hemendik eskuratua: http://webhome.phy.duke.edu/ hsg/414/files/lectures/ fourieranalysis-of-a-1d-diffusion-eq.pdf, azken bisita: 2020-10-04.

[9] KUTTLER C. 2011. Reaction-Diffusion Equations with Applications. Sommersemester. Hemendik eskuratua: http://www-m6.ma.tum.de/ kuttler/ script_reaktdiff.pdf, azken bisita: 2020-10-04.

[10] LAHOZ-BELTRA R. 2011. Las matemáticas de la vida. Modelos numéricos para la biología y la ecología. RBA Coleccionables, S.A., Rodesa, Navarra.

[11] MURRAY J. D. 2002. Mathematical Biology: I. An Introduction, Third Edition. Springer.

[12] NEUMANN J. V. 1966. Theory of Self-Reproducing Automata. Edited and completed by A. W. Burks. University of Illinois Press.

[13] NIU H-L. 2015. «Spreading speeds in a lattice differential equation with distributed delay». Turkish Journal of Mathematics, 39, 235-250.

[14] OLAIRU S. eta ZOMAYA A. Y. 2006. Handdbook of Bioinspired Algorithms and Applications. Chapman \& Hall/CRC Computer and Information Science Series (Taylor \& Francis Group), Florida, AEB.

[15] RASHEVSKY N. 1935. «Mathematical Biophysics». Nature, 135, 528-530.

[16] SPIEGEL M. R. 1974. Fourier Analysis. Rensselaer Polytechnic Institute, AEB. (Itzulpena: E. Currea, Análisis de Fourier, Bogotá, 1976). 
[17] TANGIRALA A. K. Discrete-time Fourier Series (DTFS). Hemendik eskuratua: https://nptel.ac.in/content/storage2/courses/103106123/Fourier\%20 Transforms,\%20DFT\%20and\%20Periodogram.pdf, azken bisita: 2020$10-04$.

[18] THOMPSON D. W. 1917. On Growth and Form. Cambridge University Press, Cambridge.

[19] TURING A. M. 1952. «The Chemical Basis of Morphogenesis». Phil. Trans. B, 237, No. 641, 37-72.

[20] TURING S. 2012. Alan M. Turing. Centenary Edition (col. M. DAVIS, L. IRVINE, J. F. TURING). Cambridge University Press, Ingalaterra (Itzulpena: NEIRA R. 2018. Alan M. Turing. Más que un enigma. Tecnos).

[21] YI H. Y. 2007. Turing instabilities in a S-I-R model. Rochester Institute Technology, AEB. Hemendik eskuratua: https://scholarworks.rit.edu/cgi/ viewcontent. cgi?referer=https://www.google.es/\&httpsredir=1\&article=598 $6 \&$ context $=$ theses, azken bisita: 2020-10-04.

[22] WALTER W. 1998. Ordinary Differential Equations. Springer-Verlag, New York. 
